\title{
地表変位データを用いた三次元すべり面形状の推定 \\ Estimation of three-dimensional sliding plane geometry using ground surface displacement data
}

\author{
宮澤 圭 ${ }^{\mathrm{a})}$ ，谷口 淳 ${ }^{\mathrm{b})}$ ，大上俊之 ${ }^{\mathrm{c}) *}$ ，豊田政史 ${ }^{\mathrm{c})}$ ，竹内 均 ${ }^{\mathrm{d})}$ ，吉澤孝和 ${ }^{\mathrm{c}}$
}

Kei MIYAZAWA, Atsushi TANIGUCHI, Toshiyuki OHKAMI, Masashi TOYOTA, Hitoshi TAKEUCHI and Norikazu YOSHIZAWA

\begin{abstract}
A new approach named polyhedron method is proposed for estimating underground sliding plane geometry by analyzing only ground displacement vectors. The displacement vectors are calculated from three-dimensional positional data of ground points surveyed in the landslide area at different times, and a three-dimensional underground sliding plane geometry is estimated by the polyhedron which consists of triangular surfaces. The proposed method is applied to actual landslide areas of Shin-yasu landslide and Aidoji landslide in Nagano prefecture.
\end{abstract}

Key words : underground sliding plane geometry, ground displacement data, polyhedron model, least square method

\section{和文要旨}

地すべり地の地表諸点の三次元位置の変動を，時間差のある測量で求め，得られた変位デー夕を解析してすべり面形状を推定す る手法において，新たに多面体法を考案した。これは推定すべり面の三次元形状を複数の任意形状の三角形面で構成される多面体 モデルで近似するものである。本稿では多面体法の解析手順を述べ，地すべりの活動が終息しつつある新安地すべりと，発生後ま もない相道寺地すべりにおいて取得した地表変位デー夕を使用してすべり面を推定した結果を示す。

キーワード：すべり面形状, 地表変位データ, 多面体モデル, 最小二乗法

\section{1.はじめに}

地すべり地の地表面の変状は時間差のある測量でとら えることができる。筆者らはこれまでに，地すべりの地 表変位を用いて，すべり面の位置と形状を二次元的，三 次元的に推定する解析手法を研究してきた。

これまでに報告した論文の中で，二次元解析 ${ }^{1) \text { 5) }}$ は地 すべりの主移動方向にとった投影断面図上ですべり面の 形状を円弧, 複合円弧, 多角形, 多項式曲線等で近似し て推定するものである。解析にあたっては，解析用の断 面方向のとり方と断面図上における地すべりの頭部や脚 部の境界条件の設定等に関してある程度の試行錯誤が必 要である。

二次元解析に関する海外の研究には筆者らの知る限り においてCarterらの論文价がある。これはすべり面の形 状を多角形で近似するもので，筆者らの多角形法 ${ }^{2}$ もこ れと類似の手法である。国内では羽田野ら ${ }^{7)}$ が岩殿山地 すべり地で, 変位べクトルから円弧すべりを図解的に推 定している。また，藤沢ら ${ }^{8}$ は筆者らの研究をもとに， 切土によって発生した地すべり地に扔いてすべり面を推 定している。

三次元解析占, 9) 13) は, 変位追跡点の三次元測量デー夕 を直接用い得ること，地すべり地内の頭部や側部の滑落 崖, 脚部隆起等の地表変状の発生位置をそのまま境界条 件に採用できること等の利点がある。これまではすべり

* 連絡著者/corresponding author

a ) (株) 長野技研

Naganogiken $\mathrm{Co}_{\text {. }} \mathrm{Ltd}$

b) 国土交通省

Ministry of Land, Infrastructure, Transport and Tourism

c) 信州大学

Shinshu University

厂 380-8553 長野県長野市若里 4-17-1

4-17-1. Wakasato, Nagano 380-8553

d) (株) 日さく

Nissaku Co., Ltd.
面の三次元形状を多項式による曲面方程式で推定してき た。この「多項式曲面法」では複雑なすべり面に対して は地すべり地をいくつかのグループに分割し，グループ ごとに求めたすべり曲面を連結する，という手順が必要 であった。いわゆる「複合多項式曲面法」5),11) 13) である。

本論文に示す手法は，筆者らが新たに開発した「多面 体法」と呼ぶもので, すべり面の三次元形状を任意形状 の三角形の集合体で構成される多面体を用いて推定する。 この手法は複雑なすべり面に対してもグループ分割の必 要はなく, すべてのデー夕を一括して処理することがで きるため，解析にあたっては複合多項式曲面法のような 煩わしさはなく，手順も簡便である。

多面体法の適用例を, 図一 1 に示す長野市新安地すべ りと長野県池田町相道寺地すべりについて示す。

前者は地すべり発生から 2 年後に現地測量と解析を 行った「遅延対応型」の適用例，後者は地すべり兆候の 発生から約 1 力月後に現地測量を行った「早期対応型」 の適用例である。ここで，本論文では「早期対応型」と 「遅延対応型」を次のように区分する。

早期対応型：段差・亀裂等の地表変状が顕著に発達しな い早期に観測を開始して移動ベクトルをと らえるもの。

遅延対応型：地すべりが進行し，副次すべり等の発生で 局所的な変状もかなり進んだ後に観測を開 始するもの。

両者を比較した場合，「早期対応型」は現地測量の能 率性とすべり面の推定精度の確保の上で極めて優れてお り，早期に地すべりのメカニズムをとらえて対処するこ とは，防災対策の費用対効果の面でも合理的な手法であ ると考えられる。 


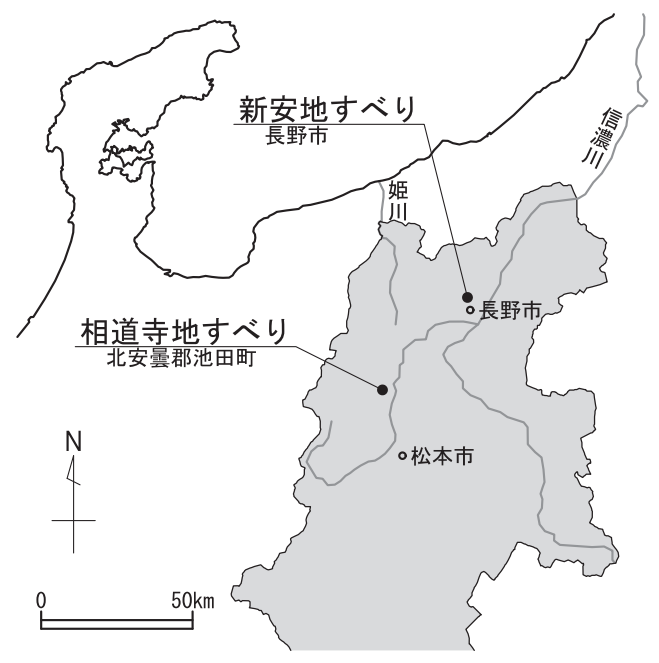

図ー 1 検討した地すべり地の位置図

Fig. 1 Location of Shin-yasu and Aidoji landslide areas

\section{2. すべり面推定の解析手法}

\section{1 解析上の仮定}

多面体法によるすべり面推定の解析手法は，すべり面 の全体形状が三次元空間上の多数の任意形状三角形で構 成された多面体で表されるものと考え，次の仮定のもと に構築されている。

仮定 1 ）地すべり地内で相互の位置関係をほぼ一定に 保ってすべり面上を変位する土塊内部の変形量は，変位 量に比べて十分に小さい。

仮定 2 ）上記の仮定 1 ）のもとで，すべり面上を変位す る土塊に設置した測点の変位ベクトルは，その鉛直下方 のすべり面形状と平行なものとなる。

\subsection{3 点を通る平面方程式}

図- 2 において直交座標系 $(x, y, z)$ 内の平面は, 次の方程式で表される。

$$
z=l \cdot x+m \cdot y+n
$$

この平面が 3 点 $a\left(x_{a}, y_{a}, z_{a}\right), b\left(x_{b}, y_{b}, z_{b}\right), c\left(x_{c}, y_{c}\right.$, $\left.z_{c}\right)$ を通る場合，上式のパラメー夕 $l, m, n$ は次のよう になる。

$$
\begin{aligned}
l= & {\left[\frac{-\left(y_{c}-y_{b}\right)}{E} \frac{-\left(y_{a}-y_{c}\right)}{E} \frac{-\left(y_{b}-y_{a}\right)}{E}\right]\left[\begin{array}{c}
z_{a} \\
z_{b} \\
z_{c}
\end{array}\right] } \\
m= & {\left[\frac{\left(x_{c}-x_{b}\right)}{E} \frac{\left(x_{a}-x_{c}\right)}{E} \frac{\left(x_{b}-x_{a}\right)}{E}\right]\left[\begin{array}{c}
z_{a} \\
z_{b} \\
z_{c}
\end{array}\right] } \\
n= & {\left[\frac{\left(y_{c}-y_{b}\right) x_{a}-\left(x_{c}-x_{b}\right) y_{a}+E}{E} \frac{\left(y_{a}-y_{c}\right) x_{a}-\left(x_{a}-x_{c}\right) y_{a}}{E}\right.} \\
& \frac{\left(y_{b}-y_{a}\right) x_{a}-\left(x_{b}-x_{a}\right) y_{a}}{E}\left[\begin{array}{c}
z_{a} \\
z_{b} \\
z_{c}
\end{array}\right]
\end{aligned}
$$

ここに

$$
E=\left(x_{c}-x_{b}\right) y_{a}+\left(x_{a}-x_{c}\right) y_{b}+\left(x_{b}-x_{a}\right) y_{c}
$$

鉛直軸を共有する 2 つの座標系 $(x, y, z),(p, q$, h）の間には，次式の関係がある。

$$
\left.\begin{array}{l}
x=p \cos \theta-q \sin \theta \\
y=p \sin \theta+q \cos \theta \\
z=h
\end{array}\right\}
$$

ここに， $\theta$ は $x$ 軸と $p$ 軸のなす水平角である。

(1)式に(4)式を代入して，平面方程式を次のように( $p$, $q, h)$ 座標系に変換する。

$$
h=(l \cos \theta+m \sin \theta) p+(-l \sin \theta+m \cos \theta) q+n
$$

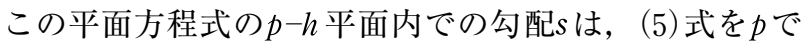
偏微分することにより求められる。

$$
s=\frac{\partial h}{\partial p}=l \cos \theta+m \sin \theta
$$

(6)式に(2)式を代入すると,

$$
\begin{aligned}
s= & {\left[\frac{\left(x_{c}-x_{b}\right) \sin \theta-\left(y_{c}-y_{b}\right) \cos \theta}{E}\right.} \\
& \frac{\left(x_{a}-x_{c}\right) \sin \theta-\left(y_{a}-y_{c}\right) \cos \theta}{E} \\
& \left.\frac{\left(x_{b}-x_{a}\right) \sin \theta-\left(y_{b}-y_{a}\right) \cos \theta}{E}\right]\left[\begin{array}{c}
z_{a} \\
z_{b} \\
z_{c}
\end{array}\right]
\end{aligned}
$$

\section{3 最小二乗法を用いた多面体頂点の高さの算出}

図-2に打いて，変位追跡点 $a^{\prime} b^{\prime} c^{\prime}$ を頂点とする三角 形状の地表面 $[i](i=1,2, \cdots, m: m$ は地表面数 $)$ の変位 方向 $D_{i}$ の水平面上の投影を $p_{i}$ 軸にとり, $x$ 軸と $p_{i}$ 軸のな す水平角を $\theta_{i}$ とする。変位方向 $D_{i}$ は地表面 $[i]$ を構成す る変位追跡点 $a^{\prime} b^{\prime} c^{\prime}$ の変位ベクトルについて, それらの 移動方向の平均をとるものとする。

変位方向 $D_{i}$ の $p_{i}-h_{i}$ 平面内の勾配を $S_{i}$, 地表面 $[i]$ の直 下にあるすべり面をあらわす三角形を $(a b c)_{i}$ (各頂点の座 標值: $a\left(x_{a}, y_{a}, z_{a}\right), b\left(x_{b}, y_{b}, z_{b}\right), c\left(x_{c}, y_{c}, z_{c}\right) ; x$, $y$ 座標值は既知）とすると, 解析上の仮定より, $p_{i}-h_{i}$ 平 面内に抢いて $S_{i}$ と三角形 $(a b c)_{i}$ の勾配が等しいとして, (7)式を用いることにより変位追跡点とすべり面の条件 式が次のように得られる。

$$
\begin{aligned}
S_{i}= & s_{i} \\
= & {\left[\frac{\left(x_{c}-x_{b}\right) \sin \theta_{i}-\left(y_{c}-y_{b}\right) \cos \theta_{i}}{E_{i}}\right.} \\
& \frac{\left(x_{a}-x_{c}\right) \sin \theta_{i}-\left(y_{a}-y_{c}\right) \cos \theta_{i}}{E_{i}} \\
& \left.\frac{\left(x_{b}-x_{a}\right) \sin \theta_{i}-\left(y_{b}-y_{a}\right) \cos \theta_{i}}{E_{i}}\right]\left[\begin{array}{l}
z_{a} \\
z_{b} \\
z_{c}
\end{array}\right]
\end{aligned}
$$

一方，すべり面を構成する三角形 $(a b c)_{k}$ の頂点 $a_{k}\left(x_{a k}\right.$, $\left.y_{a k}, z_{a k}\right)$ が，地すべり境界点 $[j]\left(x_{a k}, y_{a k}, z_{j}\right)(j=1,2$, $\cdots, n: n$ は境界点数) であるとすると，すべり面と境界 点の高さが等しいことから，次の条件式が成り立つ。

$z_{j}=z_{a k}$ 
条件式 (8)，(9)をそれぞれm個， $n$ 個作成し，これを 解くことにより，未知量である多面体の頂点の $Z$ 座標 $\left\{z_{1}, z_{2}, \cdots, z_{l}: l\right.$ は変位追跡点数 + 境界点数 $\}$ を求め ることが可能となる。しかし一般には，条件式の数 $(m$ $+n)$ と未知量の数 $(l)$ は必ずしも一致しないこと，ま た変位追跡点と境界点の座標值，及び解析上の仮定に起 因する誤差を処理する必要があるため，最小二乗法を用 いて未知量を求める。

式(8)，(9)に生じる残差vは，次のと抒りである。

$$
\begin{aligned}
v_{i}= & {\left[\frac{\left(x_{c i}-x_{b i}\right) \sin \theta_{i}-\left(y_{c i}-y_{b i}\right) \cos \theta_{i}}{E_{i}}\right.} \\
& \frac{\left(x_{a i}-x_{c i}\right) \sin \theta_{i}-\left(y_{a i}-y_{c i}\right) \cos \theta_{i}}{E_{i}} \\
& \left.\frac{\left(x_{b i}-x_{a i}\right) \sin \theta_{i}-\left(y_{b i}-y_{a i}\right) \cos \theta_{i}}{E_{i}}\right]\left[\begin{array}{c}
z_{a i} \\
z_{b i} \\
z_{c i}
\end{array}\right]-S_{i}
\end{aligned}
$$

$v_{j}=z_{a k}-z_{j}$

すべての残差式は次の形にまとめることができる。

$$
\mathrm{V}=\mathrm{P} \cdot \mathrm{Z}-\mathrm{S}
$$

ここに，Vは残差べクトル，PとSは定数項を示す行列及 びベクトル，Zは未知量ベクトルである。最小二乗法の 正規方程式は，P，Z，S及び重みW（対角行列）を用い て次のようになる。

$$
\mathrm{P}^{\top} \cdot \mathrm{W}(\mathrm{P} \cdot \mathrm{Z}-\mathrm{S})=0
$$

ここに $\mathrm{P}^{\top} は \mathrm{P} の$ 転置行列である。なお，重みを考慮し ない場合，Wは単位行列となる。これを解いて未知量べ クトルZを求める。

\section{4 滑落崖ベクトルの導入}

地すべりの境界を示す滑落崖の露頭面の傾斜を，そこ を滑落した土塊の変位べクトルとみなすことができる。 これを「滑落崖べクトル」と呼び，その方向を変位方向 $D_{i}$ の計算に加える。滑落崖べクトルを解析に加えるこ とは新しい試みであるが，これはこれまでに提案してき

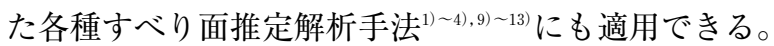

\section{3. 新安地すべり地への適用}

\section{1 新安地すべりの概要}

新安地区は, 長野盆地西縁の南浅川沿いの山中に位置 する。地すべりは南浅川の右岸側斜面において 2005 年 3 月末頃の市道の変状の発生から始まり，2006年 3 月〜 4 月の融雪水による変動が顕著になり，同年 7 月下旬の梅 雨前線豪雨によってさらに地すべり活動が進行し，亀 裂・崩壊等の変状が拡大した。地すべりの規模は，幅・ 延長とも約 $70 \mathrm{~m}$ ，すべり面深度は最大で $15 \mathrm{~m}$ 程度である。 この地すべりの移動土塊は風化泥岩を主体とし，すべり 面は椅子型の形態をなしていることが既往調査で確認さ れている ${ }^{14)}$ 。

調査・測量を行った 2008 年11月〜2009年 5 月の期間に おいては，活発な動きは見られず，終息傾向にあったも のと考えられる。

図 -3 ，図-4は地すべり発生当初の現地の平面図及 び断面図で，調査ボーリングの位置や，市道新安畑山線 の復旧計画が示されている。平面図の滑落崖や亀裂は, 今回の調査で行った測量の結果である。

\section{2 変位追跡点の測量}

変位追跡点を木杭の他，切株や伸縮計可動端・固定端 に設置した。測量を行った時期は, 1 回目の測量は積雪 前の2008年11月の 3 日間，2回目は融雪後の2009年 4 月

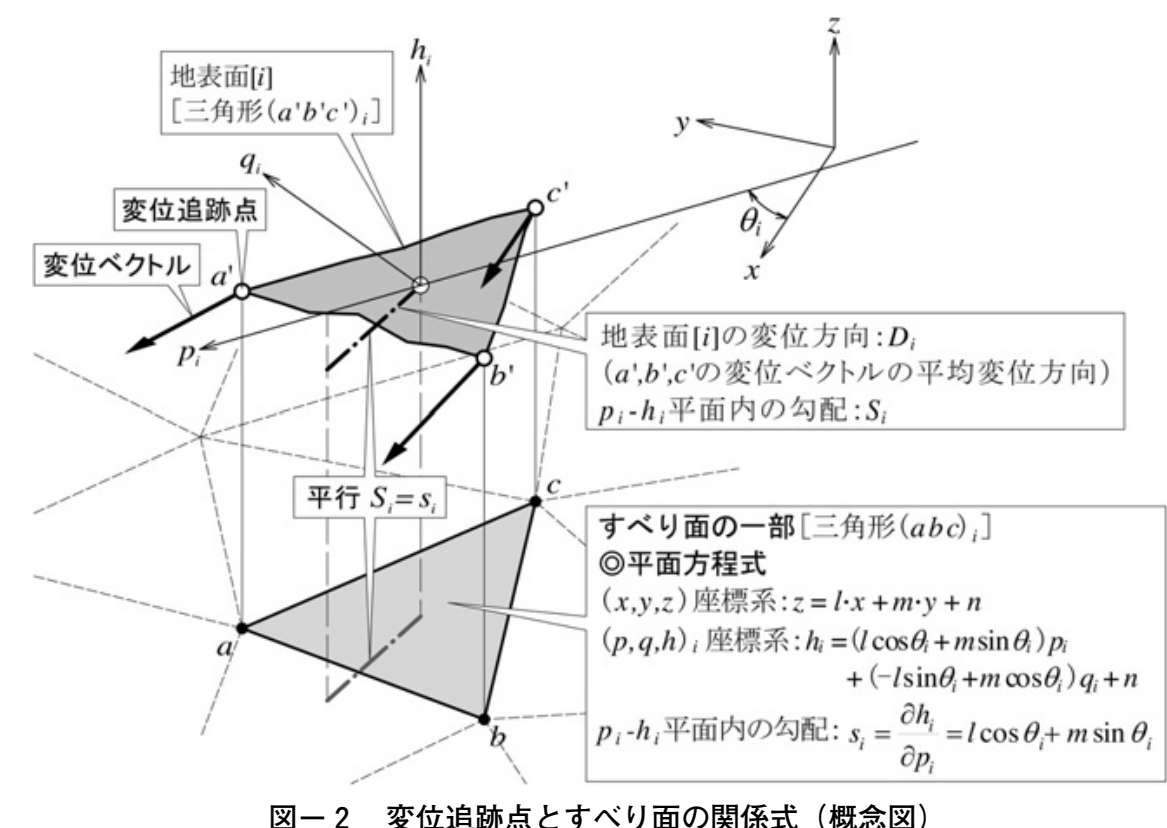

Fig. 2 Relationship between ground displacement vectors and sliding surface 


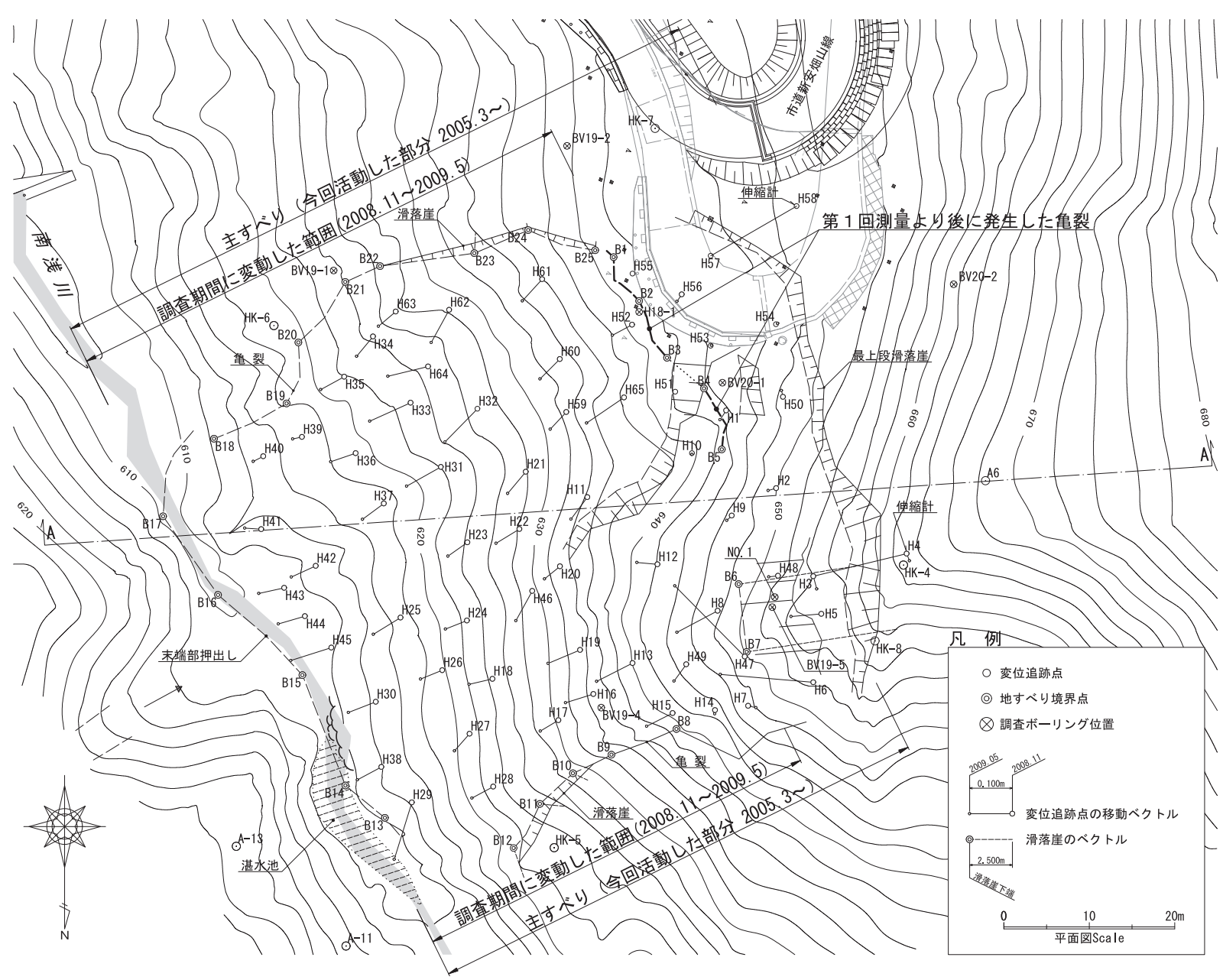

図ー3 新安地すべり平面図及び変位ベクトル図（長野県長野地方事務所提供資料に加筆）

Fig. 3 Displacement vectors of Shin-yasu landslide

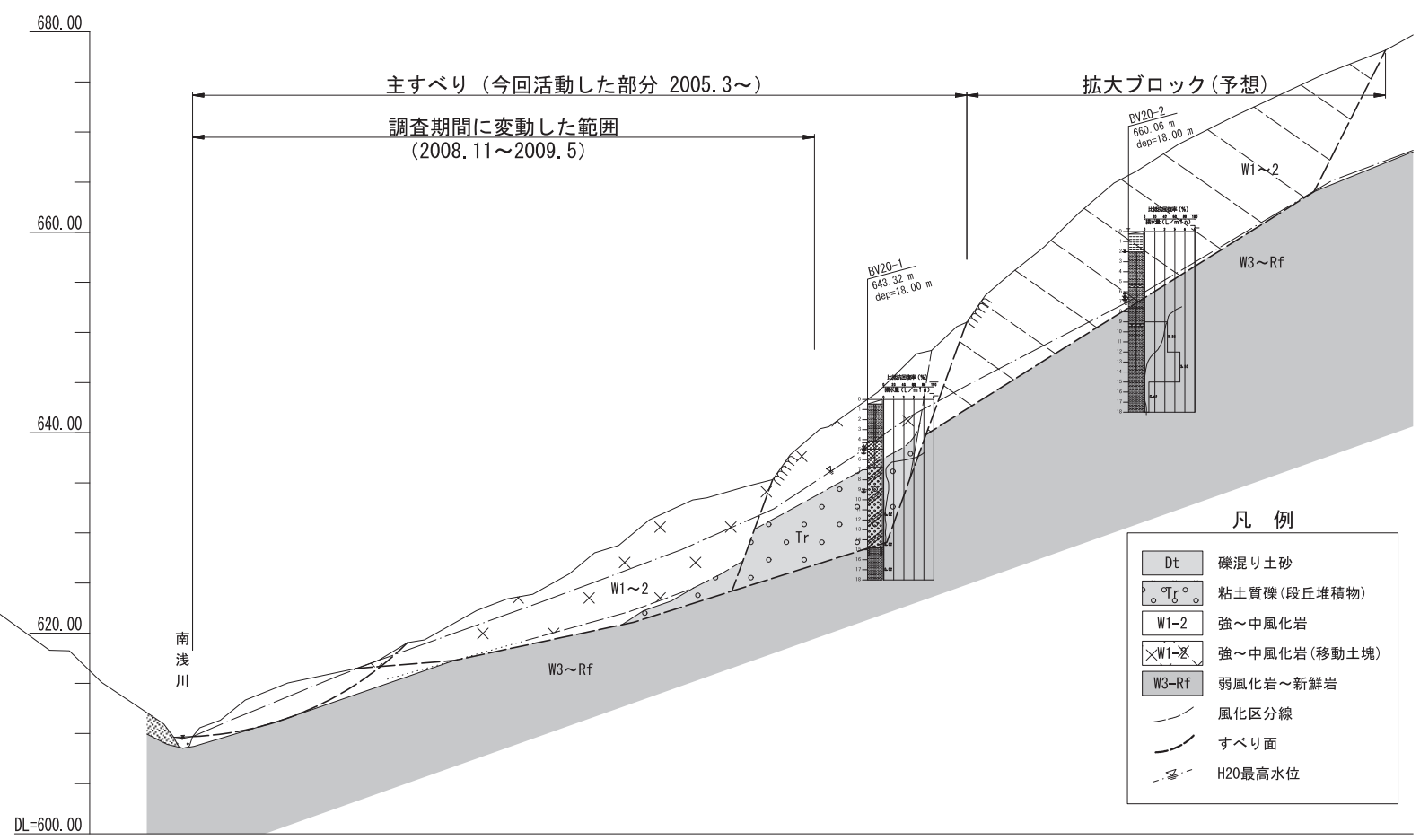

図一４新安地すべり断面図（図一 $3 \mathrm{~A}-\mathrm{A}$ ）(長野県長野地方事務所提供に加筆）

Fig. 4 Cross section diagram of Shin-yasu landslide (A-A section in Fig. 3) 
の 3 日間で，トータルステーションを用いて観測を行い， 図ー 3 に示すように変位ベクトルを得た。

\section{3 变位追跡点以外の測量}

地すべり境界点となる滑落崖や亀裂の三次元位置を測 量している。滑落崖では露頭面の勾配を得るため，その 上下を測った。第 1 回測量より後にB 1 〜 B 5 に亀裂が 発生しており，第 2 回測量時にこの亀裂の位置を測った。

\section{4 解析に使用する変位追跡点の選定}

伸縮計固定端に設置した 4 で $2 \mathrm{~cm}$ 程度の変位が認 められるため, 測量誤差は $2 \mathrm{~cm}$ 程度であると考えられ る。新安地すべりについては, 平面図上の変位量が 5 〜 $10 \mathrm{~cm}$ に対し $2 \mathrm{~cm}$ 程度の誤差が見込まれ，変位量に対す る誤差の比率が大きく，平面図上に扔いても変位量や変 位方向のバラッキが後述の相道寺地すべりに比べて多い。

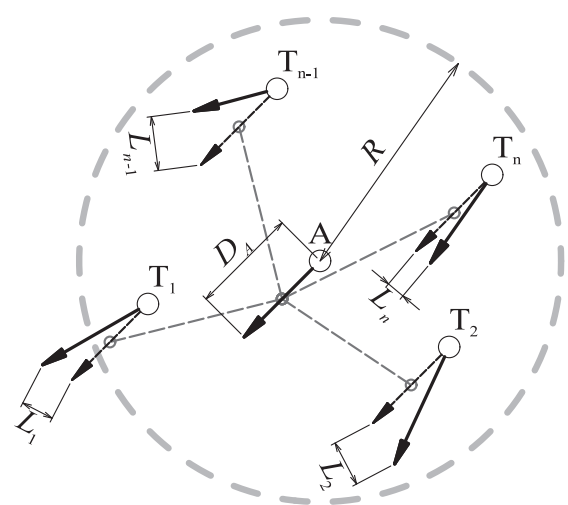

図－5 変位追跡点の選定

Fig. 5 Adoption way of tracking points
現場の測量環境の厳しさに伴う誤差を考虑して，解析に 用いる変位追跡点を次の手順により選定した。

（1）変位していないと判断した変位追跡点，測量作業の ミスと判断した変位追跡点を除外する。

（2）図-5の変位追跡点Aを選定対象とする場合，A点 の半径 $R$ の中にある測点 $\mathrm{T}_{1} \sim \mathrm{T}_{\mathrm{n}}$ を抽出する。

（3）測点 $\mathrm{T}_{1} \sim \mathrm{T}_{\mathrm{n}}$ にA点の変位ベクトルを重ね，その先端 と測点 $\mathrm{T}_{1} \sim \mathrm{T}_{\mathrm{n}}$ の変位ベクトルの先端との距離 $L_{1} \sim L_{\mathrm{n}}$ を求める。

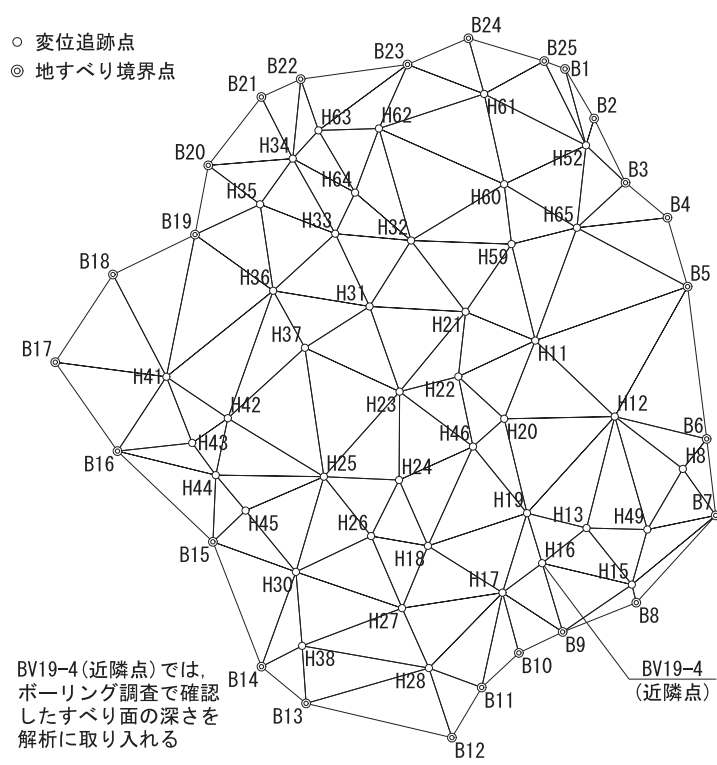

図ー6 新安地すべり解析用TINモデル

Fig. 6 TIN model for Shin-yasu landslide

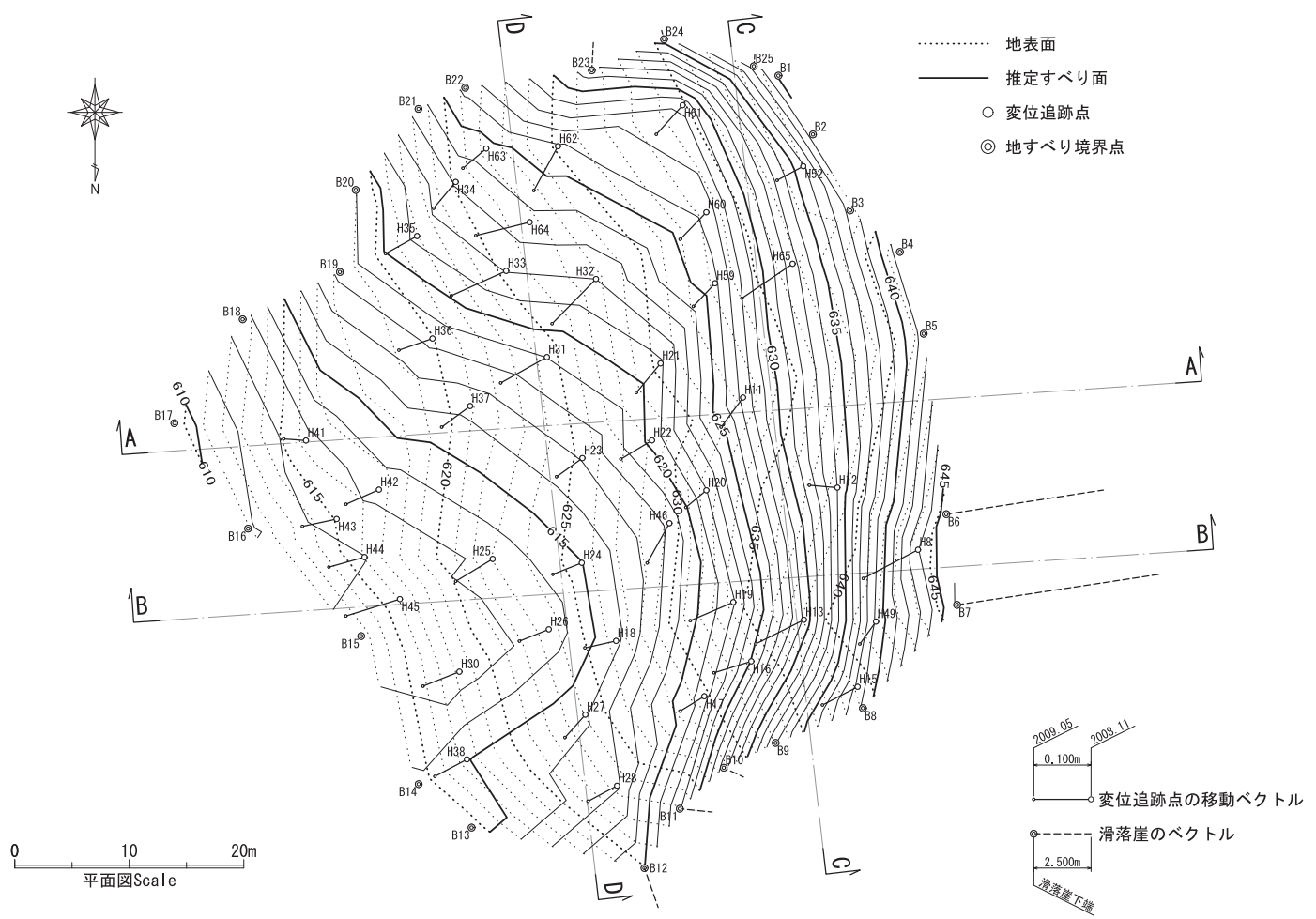

図ー 7 新安地すべり解析条件(1)：ボーリングデータを用いない推定結果平面図（等高線表示）

Fig. 7 Plane figure of sliding shape of Shin-yasu landslide under the analytical condition 1 (not using boring data) 


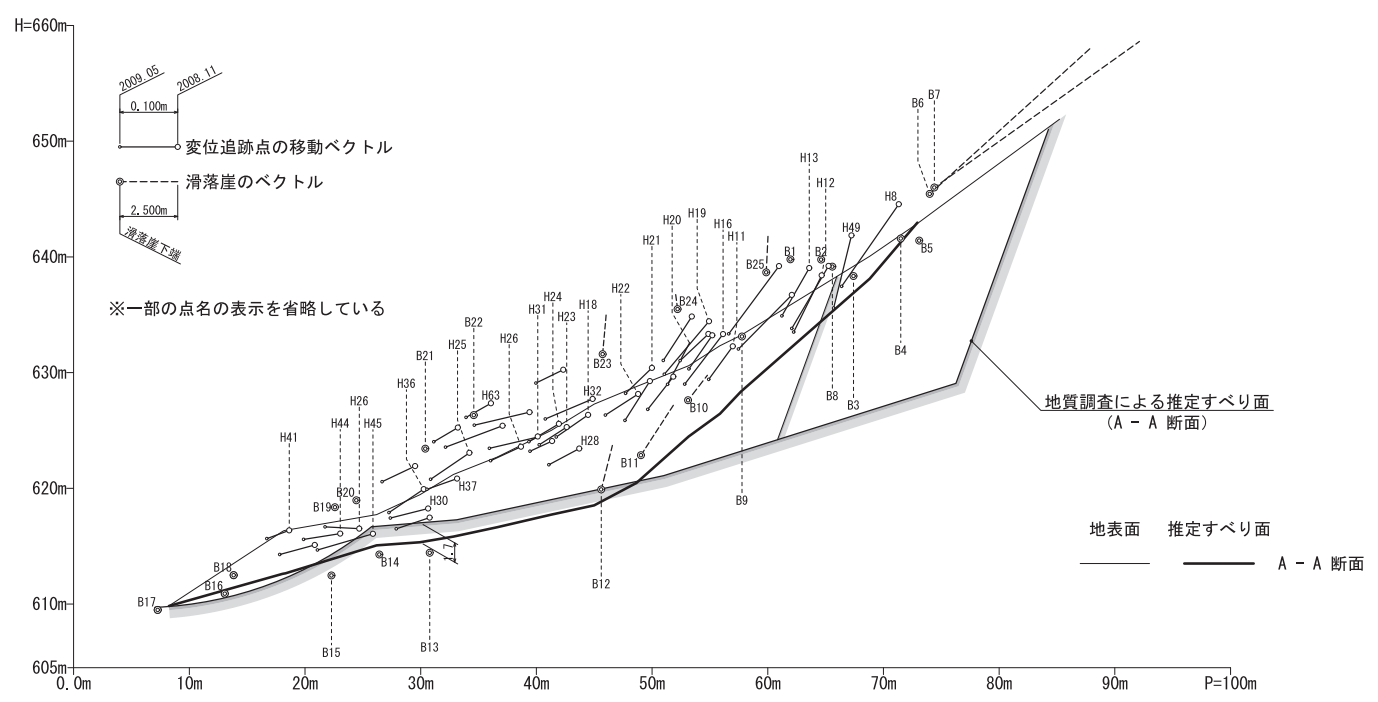

（a）縱断方向（斜面傾斜方向） A - A 断面

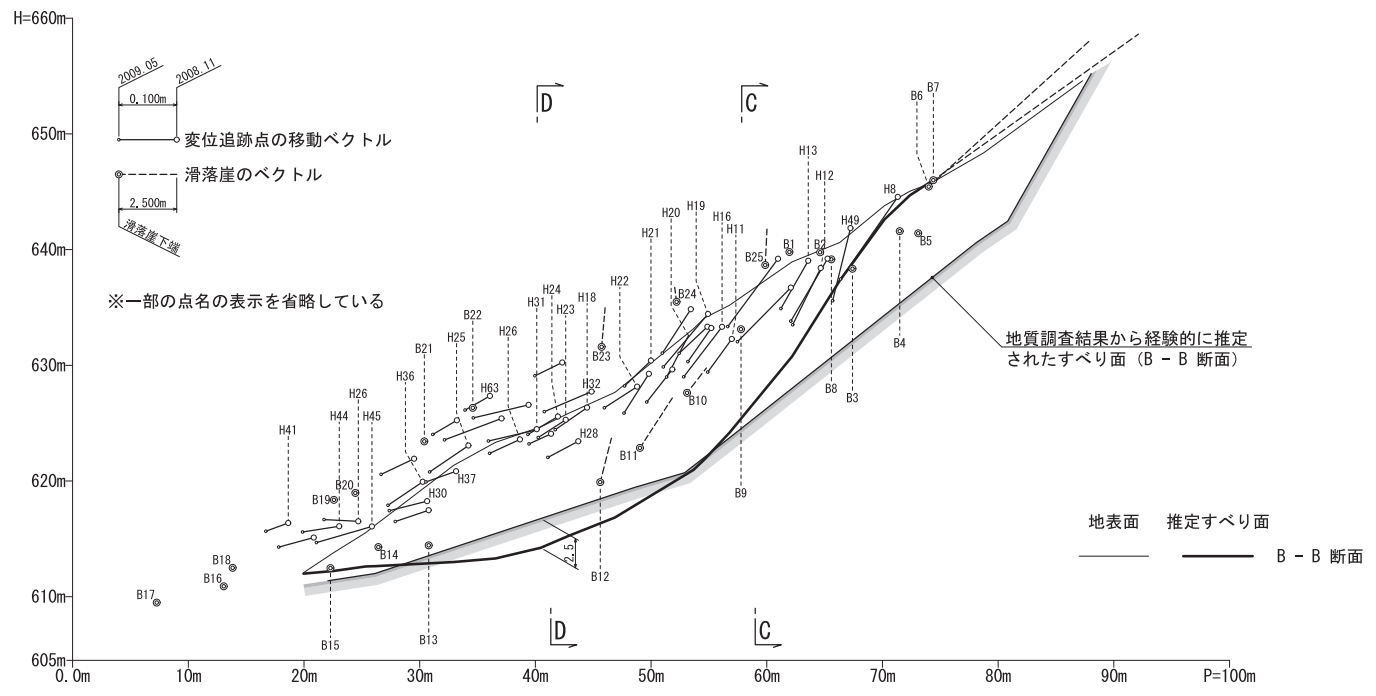

(b) 縦断方向（斜面傾斜方向）B - B 断面

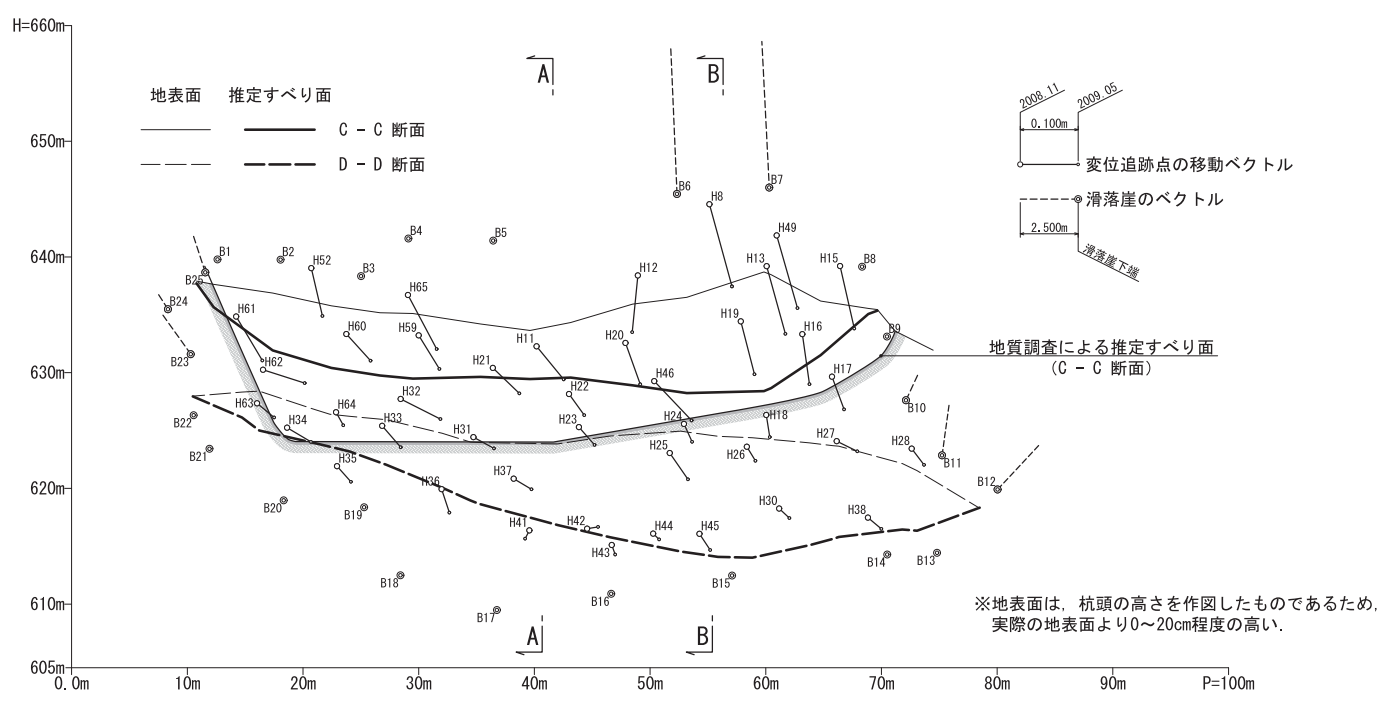

(c) 横断方向（斜面傾斜直角方向）断面図

図一8 新安地すべり解析条件(1)：ボーリングデータを用いない推定結果断面図

Fig. 8 Cross section diagram of sliding shape of Shin-yasu landslide under the analytical condition 1 (not using boring data) 
（4） $L_{1} \sim L_{n}$ の平均值 $L_{\mathrm{M}}$ が基準值 $S_{1}$ より小さい場合，かつ $L_{\mathrm{M}}$ を A点の変位量 $D_{\mathrm{A}}$ で割った值 $L_{\mathrm{M}} / D_{\mathrm{A}}$ が基準值 $S_{2}$ よ り小さい場合，A点を解析に採用する。

（5）（2）～(4)をすべての変位追跡点に関して行う。

基準值 $S_{1}, S_{2}$ は解析に使用する変位追跡点の数，配置 状況等を考慮して適宜に設定する。新安地すべりでは変 位追跡点が 40 点程度となるように $R=20 \mathrm{~m}, S_{1}=0.1 \mathrm{~m}, S_{2}$ $=1.0$ に設定した。その結果，設置した変位追跡点65点 のうち42点のデータを採用した。

\section{5 すべり面の推定}

3.4で選定した変位追跡点（42点）は，図－3に示す 第 1 回測量より後に発生した亀裂より下側に設置したも のである。よってここで推定するすべり面は，この亀裂 を境界点として用い，調査期間において変動した部分に ついて推定する。図- 3 に示す最上段の滑落崖を含めた 2005年 3 月以降に活動した全体のすべり面を推定するも のではない。

上記の変位追跡点（42点）及び地すべり境界点（26点, このうち滑落崖ベクトルを有する 8 点，ボーリング調査 地 1 点)の計68点について, 図- 6 のようにTINモデルを 設定し，次の 2 つの条件ですべり面の推定解析を行った。 解析条件(1)：ボーリング調査結果を用いない

解析条件(2)：BV19-4のボーリング調査結果をすべり面 の既知深度として用いる

解析条件(1)の推定結果を図 - 7 (平面図)，図 - 8 (断 面図）に示す。 $\mathrm{A}-\mathrm{A}, \mathrm{B}-\mathrm{B}, \mathrm{C}-\mathrm{C}$ 断面に対して，「地質
調査による推定すべり面」が報告されているので，図一 8 にこれらと本手法による推定結果との比較を示す。こ れと本手法による推定結果を比較すると，本手法は調査 期間内での変動に対して適用したものであるため，頭部 （C-C断面位置より上方）では，推定すべり面の形状は 全く一致しないが， C-C断面位置より下方では，本手法 による推定すべり面は「地質調查による推定すべり面」 に近づく。しかし，本手法の方が涾くなり，A-A断面 では最大 $1.7 \mathrm{~m}, \mathrm{~B}-\mathrm{B}$ 断面では最大 $2.5 \mathrm{~m}$ の差が生じてい る。また「地質調査による推定すべり面」は，直線的な 形状（多角形）となっているが，本手法による推定すべ り面はB-B断面では円弧状となっている。

平面図の推定すべり面の等高線に着目すると，平面図 南側（上側）ではH60，H61を境に，頭部側は等高線の 間隔が狭く，脚部側では間隔がほぼ一定で広くなってお り，典型的な椅子型の断面形状になっていることが推測 できる。

A-A断面において，本手法による推定すべり面も椅 子型に分類される形状となっているが，頭部側の勾配が 緩い。等高線では頭部中央部の勾配が，その両側に比べ て緩くなっている。またC-C断面では推定すべり面が中 央部で上に凸になっている。これは頭部中央部における 変位追跡点が少ないことによる解析データ不足のためで あると考えられる。図－60解析モデルではこの部分の 三角形の面積が大きい。

解析条件(2)の推定結果を図-9，図-10に示す。解析

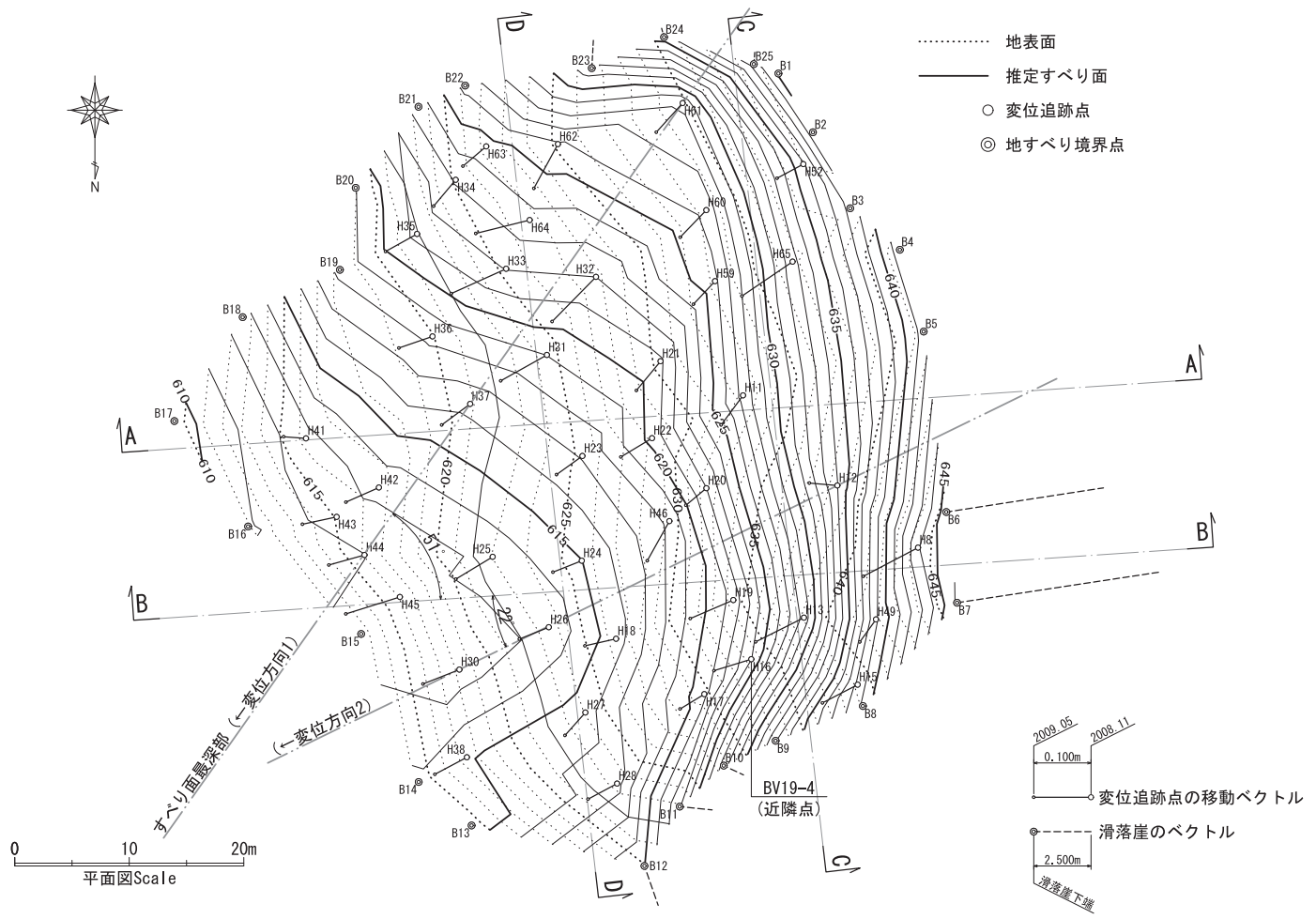

図ー9＼cjkstart新安地すべり解析条件(2)：ボーリングデータBV19-4を用いた推定結果平面図（等高線表示）

Fig. 9 Plane figure of sliding shape of Shin-yasu landslide under the analytical condition 2 (using the bore hole BV 19-4 data) 


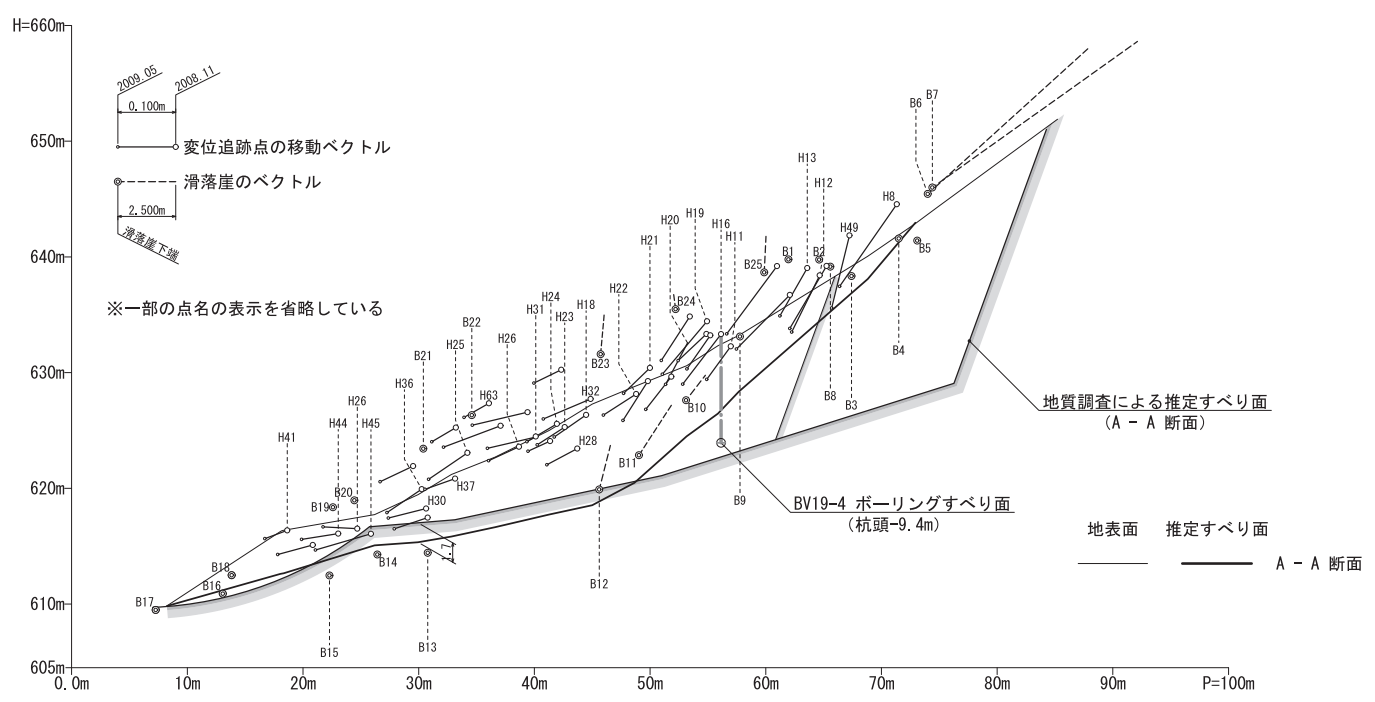

（a）縱断方向（斜面傾斜方向） A - A 断面

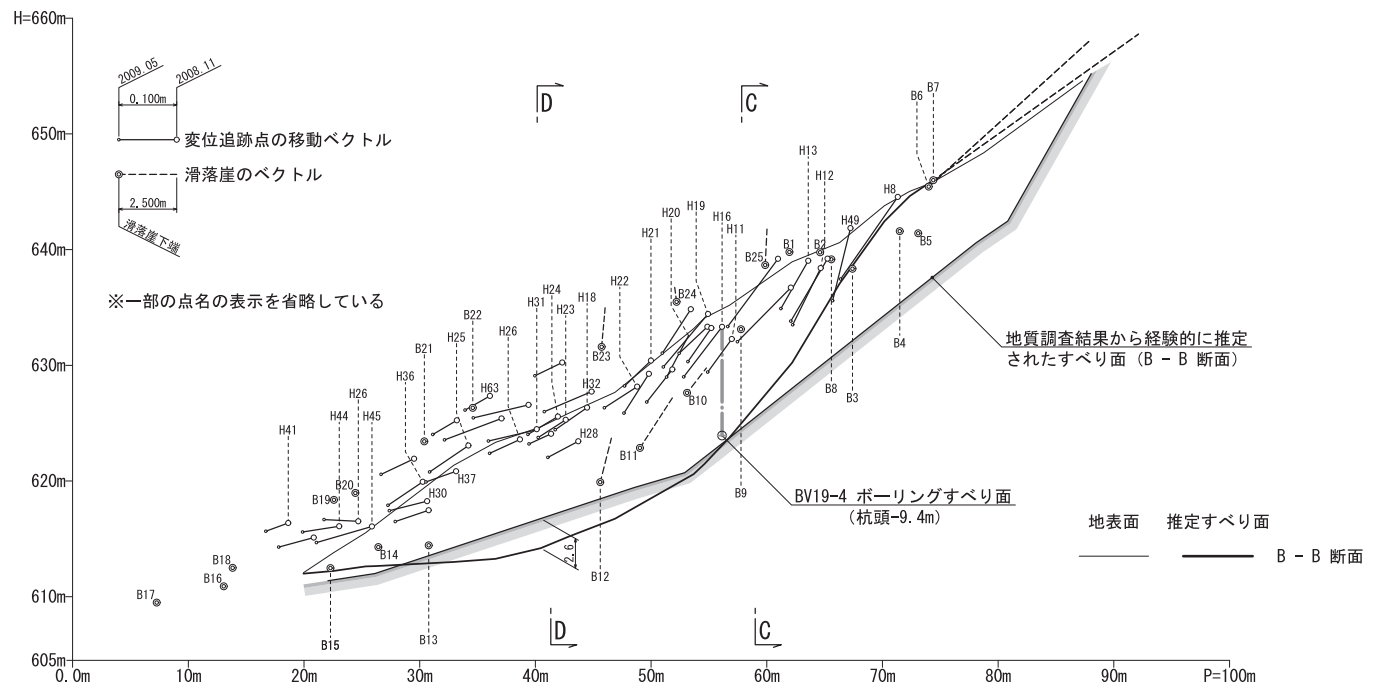

(b) 縦断方向（斜面傾斜方向）B - B 断面

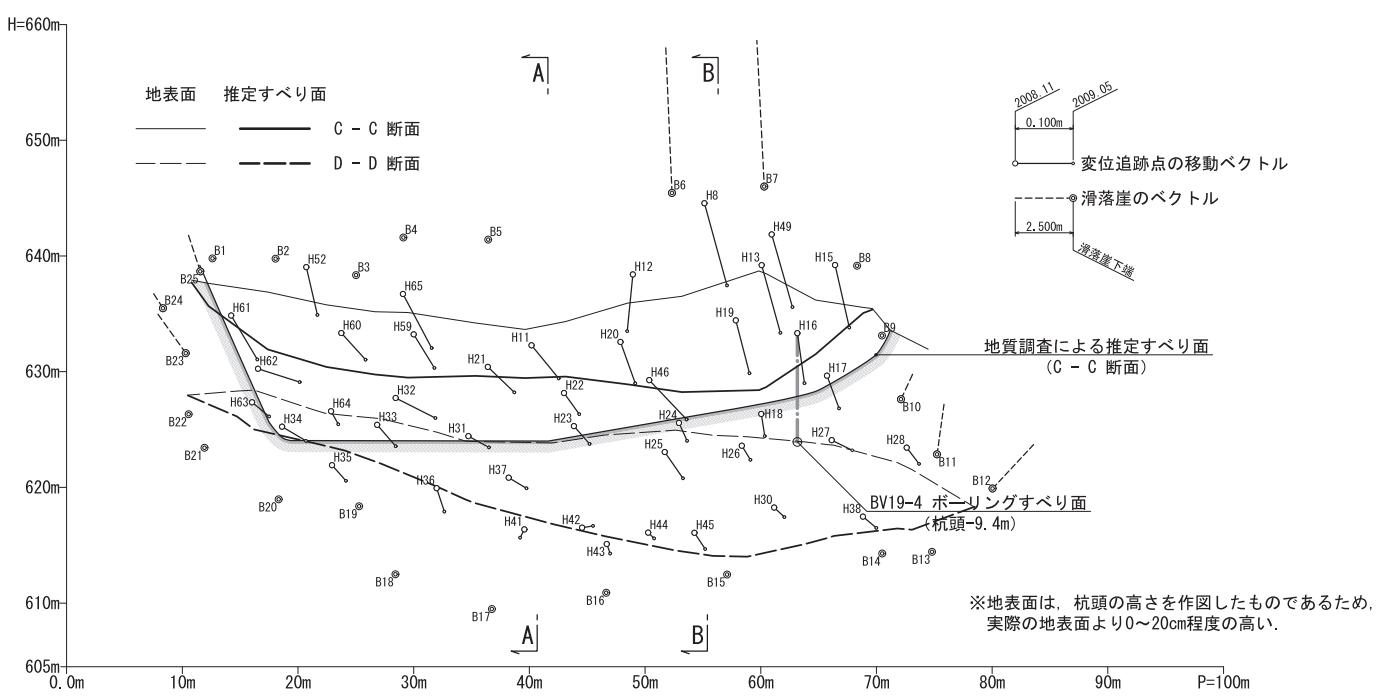

(c) 横断方向（斜面傾斜直角方向）断面図

図ー10 新安地すべり解析条件(2)：ボーリングデータBV19-4を用いた推定結果断面図

Fig. 10 Cross section diagram of sliding shape of Shin-yasu landslide under the analytical condition 2 (using the bore hole BV 19-4 data) 


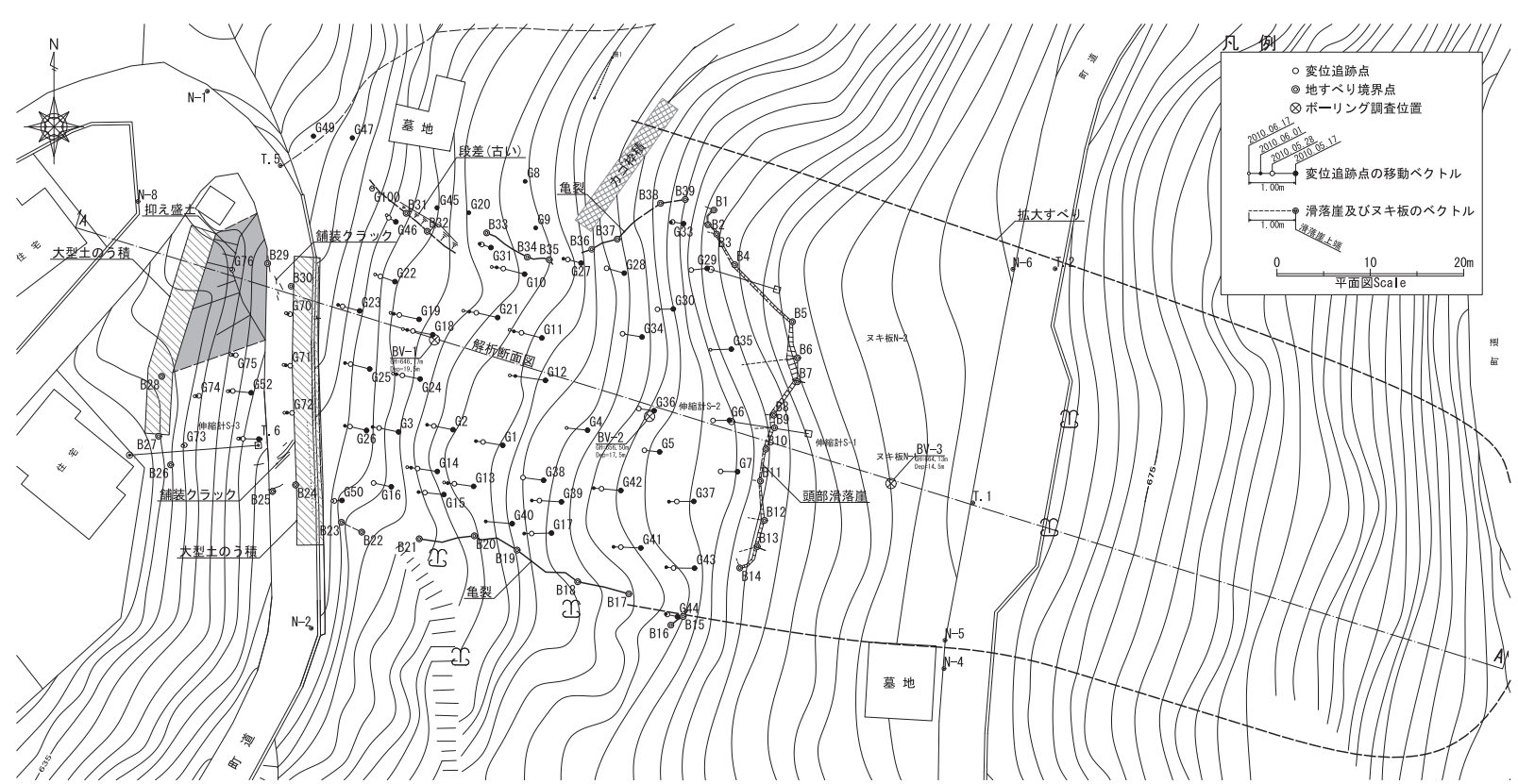

図-11 相道寺地すべり平面図及び変位べクトル図（長野県犀川砂防事務所提供資料に加筆）

Fig. 11 Displacement vectors of Aidoji landslide

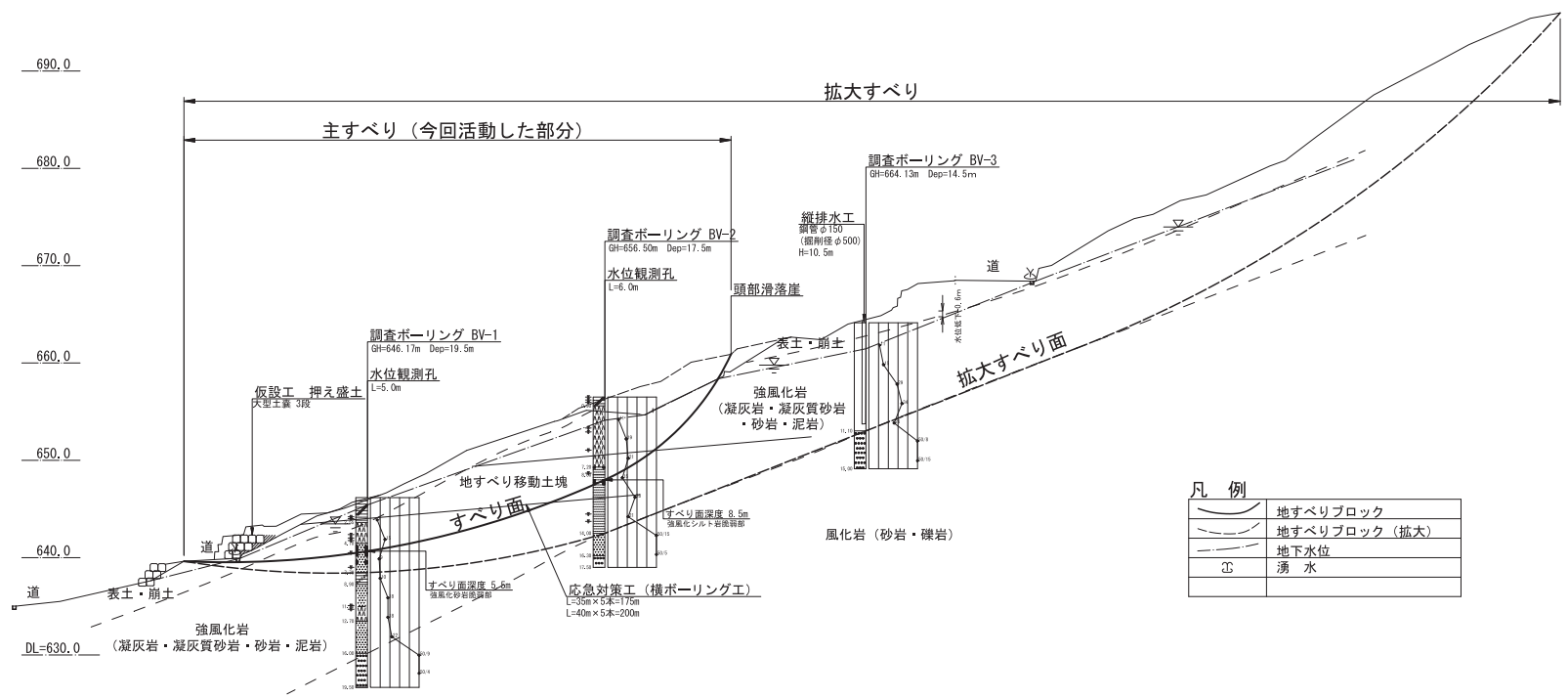

図一12 相道寺地すべり断面図（図一11A-A)（長野県犀川砂防事務所提供）

Fig. 12 Cross section diagram of Aidoji landslide (A-A section in Fig. 11)

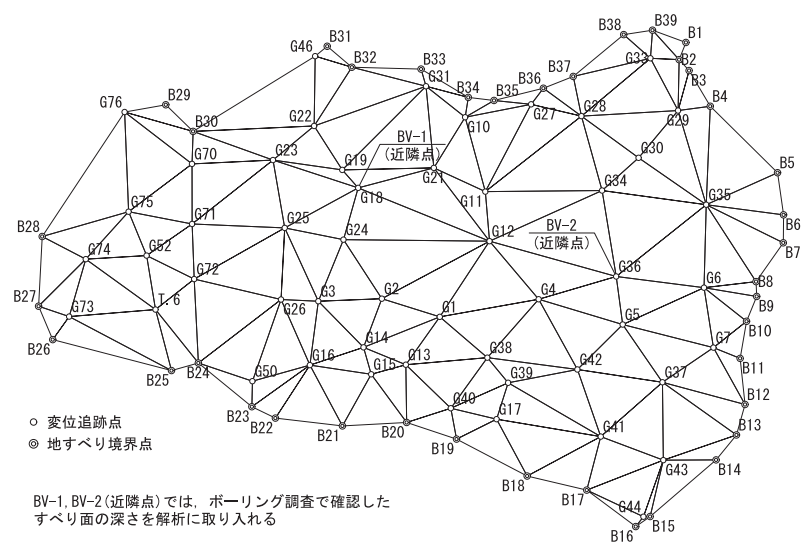

図一13 相道寺地すべり解析用TINモデル

Fig. 13 TIN model for Aidoji landslide
結果(1)に類似した結果となった。B-B断面で推定すべり 面が解析結果(1)に比べて数センチ深くなった程度で，A -A断面ではほとんど変化がなかった。平面図で比較す ると，解析条件(2)の方がH13，H16，H17周辺で等高線 が $1 \mathrm{~m}$ 程度深くなっている。

本手法による推定すべり面が，「地質調査による推定 すべり面」と比較して脚部で深くなった要因としては, 地質調査を行った時期に比べ，今回の調査した時期は， 地すべりが進行し，末端部押出しの位置が南浅川（北西 側）の方へ移動したため，脚部の境界点の位置を地質調 查当初より低い位置に設定したことによるものと考えら れる。

推定結果平面図（図－9）によると，本解析法による 推定すべり面では，H37とH61を結んだ線付近にすべり 


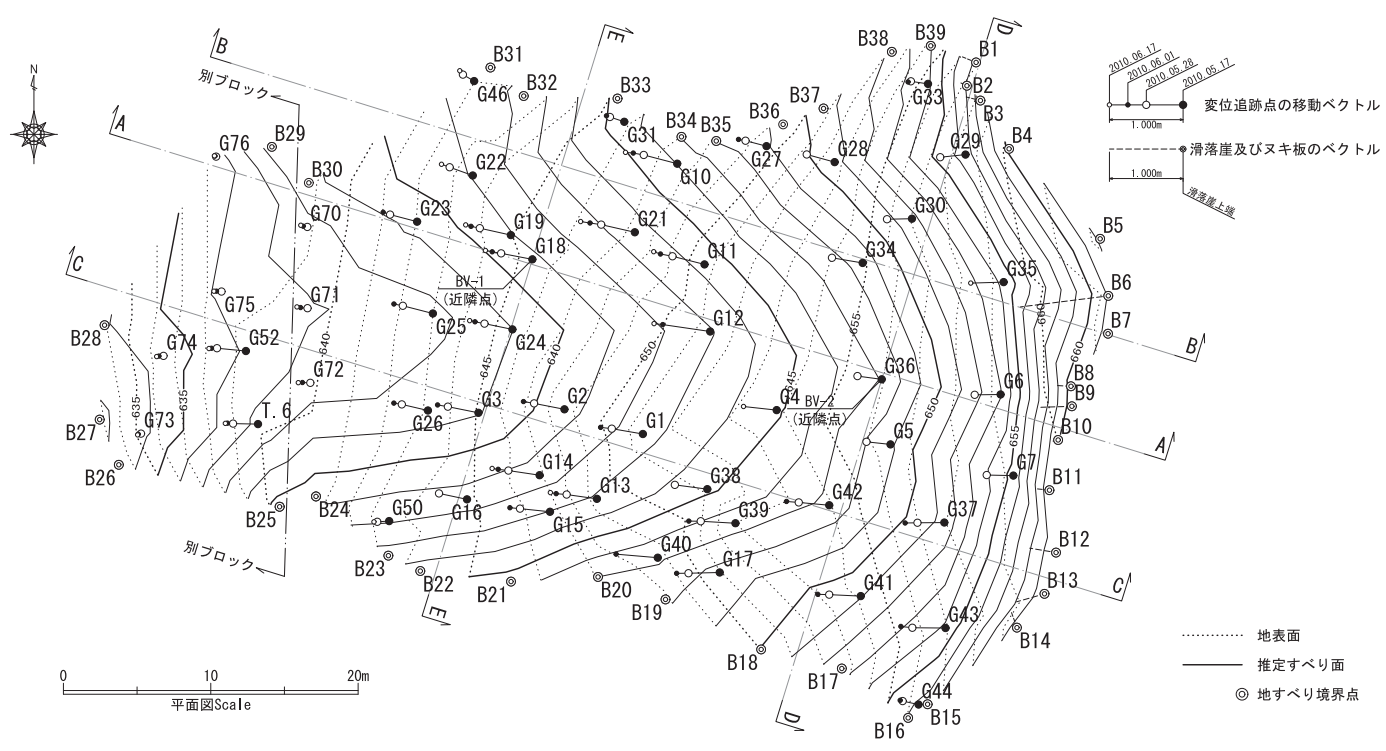

図ー14 相道寺地すべり解析条件 1 ：ボーリングデータを用いない推定結果平面図（等高線表示）

Fig. 14 Plane figure of sliding shape of Aidoji landslide under the analytical condition 1 (not using boring data)

面の最深部があり, A-A・B-B測線より反時計回りに $51^{\circ}$ 程度の角度差がある。 $\mathrm{A}-\mathrm{A}$ 測線周辺から南側の測点は 概ねこの方向に変位していることがわかる。これより北 側の測点は概ねH30とH12を結んだ線の方向に変位して いる。この方向も $\mathrm{A}-\mathrm{A} ・ \mathrm{~B}-\mathrm{B}$ 測線より反時計回りに $22^{\circ}$ 程度の角度差がある。A-A・B-B測線は地すべり発生当 初の全体すべりについて，数点の変位観測結果をもとに 設定されたものであるが，本研究で解析対象とした斜面 中腹より下方のすべりは変位方向がこれとは異なってい る。これより今回の調查期間における地表の変位方向及 びすべり面の推定結果は，全体すべりとは異なる副次的 なすべりをとらえているものと考えられる。

\section{4. 相道寺地すべり地への適用}

\section{1 相道寺地すべりの概要}

相道寺地すべりは, 長野県北西部の北安量郡池田町相 道寺地区の住宅地背後の斜面で2010年 4 月に発生した。 4 月21日に町道舗装の隆起や擁壁のクラックや傾倒等を 確認，その後の調査で上方の斜面で亀裂等が確認された。 応急対策工事 (脚部の横孔ボーリング) が行われたが，5 月23日・24日の降雨により大きく変位した。これに伴う 追加の応急対策として脚部の押え盛土，上部の土砂の排 除, 頭部滑落崖上方での縱排水工が行われた。これによっ て，本稿執筆の段階（2010年12月）では活動がほぼ停止 した状態となっており，対策本工事が行われている。現 地の平面図及び断面図を図-11，図-12に示す。

\section{2 変位追跡点の測量}

変位追跡点の測量は，2010年 5 月17日・28日，6月 1 日・17日の合計 4 回トータルステーションを使用して 行った。変位追跡点は木杭・測量ピンの他, 既存測点 伸縮計可動端や伐採木の切株に設定した。また，G18， G36はボーリング点（それぞれBV-1, BV-2）の近隣に
設置した。

\section{3 変位追跡点以外の測量}

新安地すべりと同様に，滑落崖や亀裂の三次元位置を 計測している。頭部滑落崖と南側の側方亀裂は 5 月17日 の段階で確認できたが，北側の側方亀裂は大きな变位が 起こった 5 月 28 日以降に明瞭に現れた。その他，道路舗 装面に発生した亀裂を計測している。末端部は地表面の 状況や樹木の傾きから判断してその位置を測ったが，押 え盛土の設置後の作業となったため狭い範囲しか確認で きなかった。

\section{4 すべり面の推定}

各変位追跡点の変位ベクトルを図-11に示す。この中 で，5月17日に設置した点は 5 月 28 日の測量で $50 \mathrm{~cm}$ 前後 の大きな変位量を得ることができた。変位量が少ない点 （G70～G76）は 5 月28日以降に設置したものであるが， 変位追跡点全体を観測期間毎にみると各変位追跡点の変 位量および変位の方向はほぼ一致している。カゴ枠積下 の土地の変位を確認するために設置したG9，G20等の変 位量は $1 \mathrm{~cm}$ 弱であることから, 変位していないと判断 した。これにより測量誤差は $1 \mathrm{~cm}$ 程度と考えられる。

相道寺地すべりでは，新安地すべりに比べて変位量に 対する測量誤差の比率が小さく，また変位量・変位方向 のバラッキが少ないことから，単純化のため，変位追跡 点デー夕の選定（3.4の手順 (2)〜 (4)) は行わないものと した。

変位していることを確認した変位追跡点（51点）及び 地すべり境界点（41点，このうち滑落崖ベクトルを有す る点10点，ボーリング調査地 2 点）の測量成果から, 図 -13に示すTINモデルを作成し，次の 4 つの条件で解析 を行った。

解析条件(1)：ボーリング調查結果を用いない

解析条件(2)：BV-2 のボーリング調査結果をすべり面の 


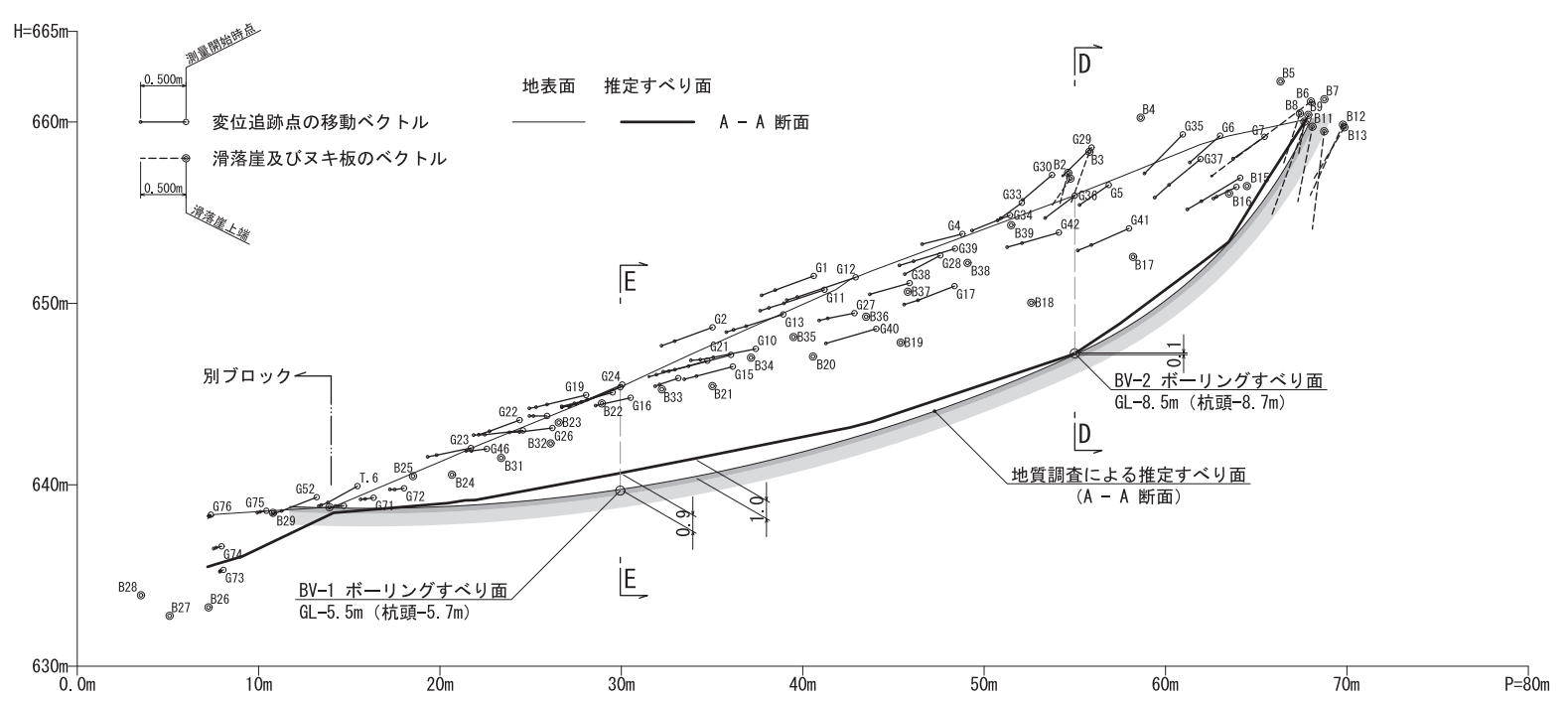

(a) 縦断方向（斜面傾斜方向） A - A 断面

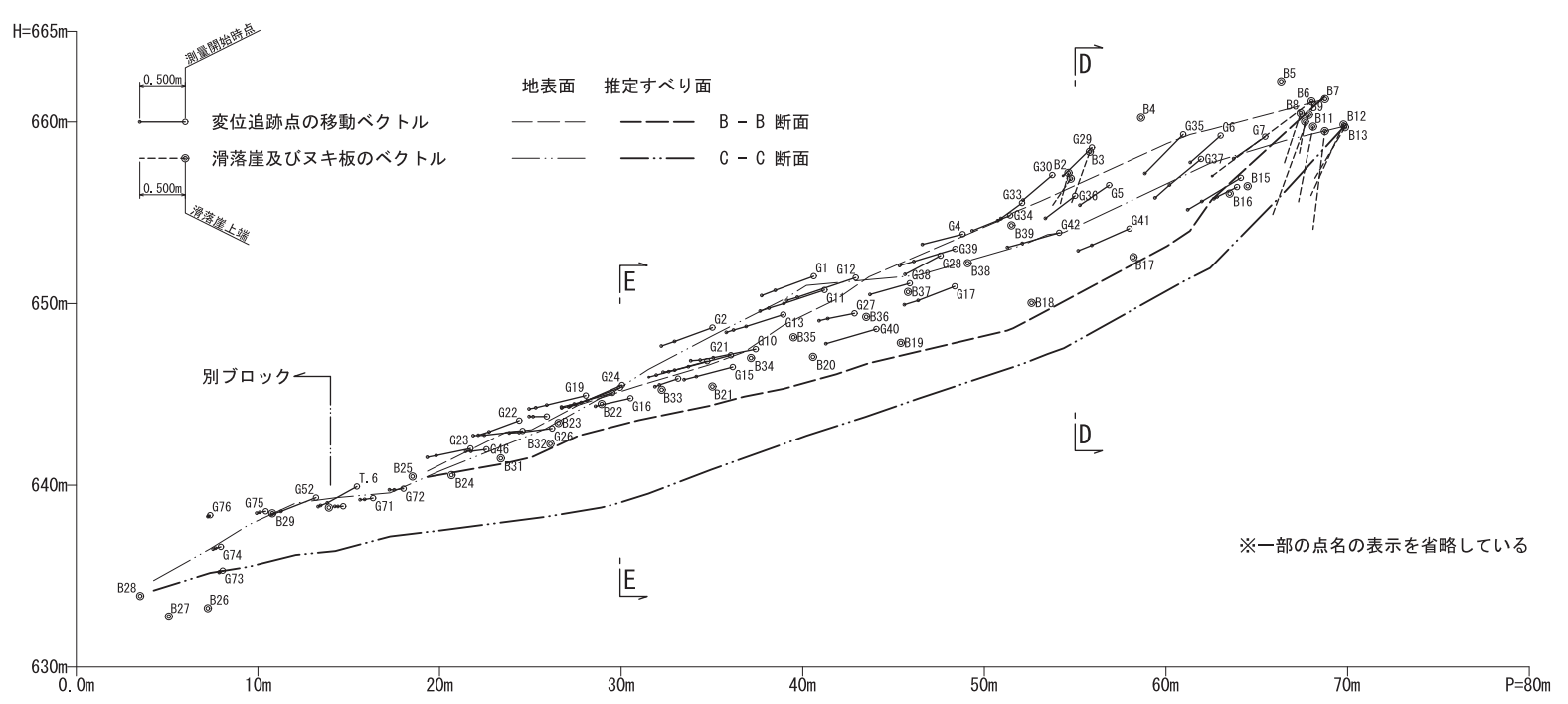

(b) 縦断方向（斜面傾斜方向）B-B, C - C 断面

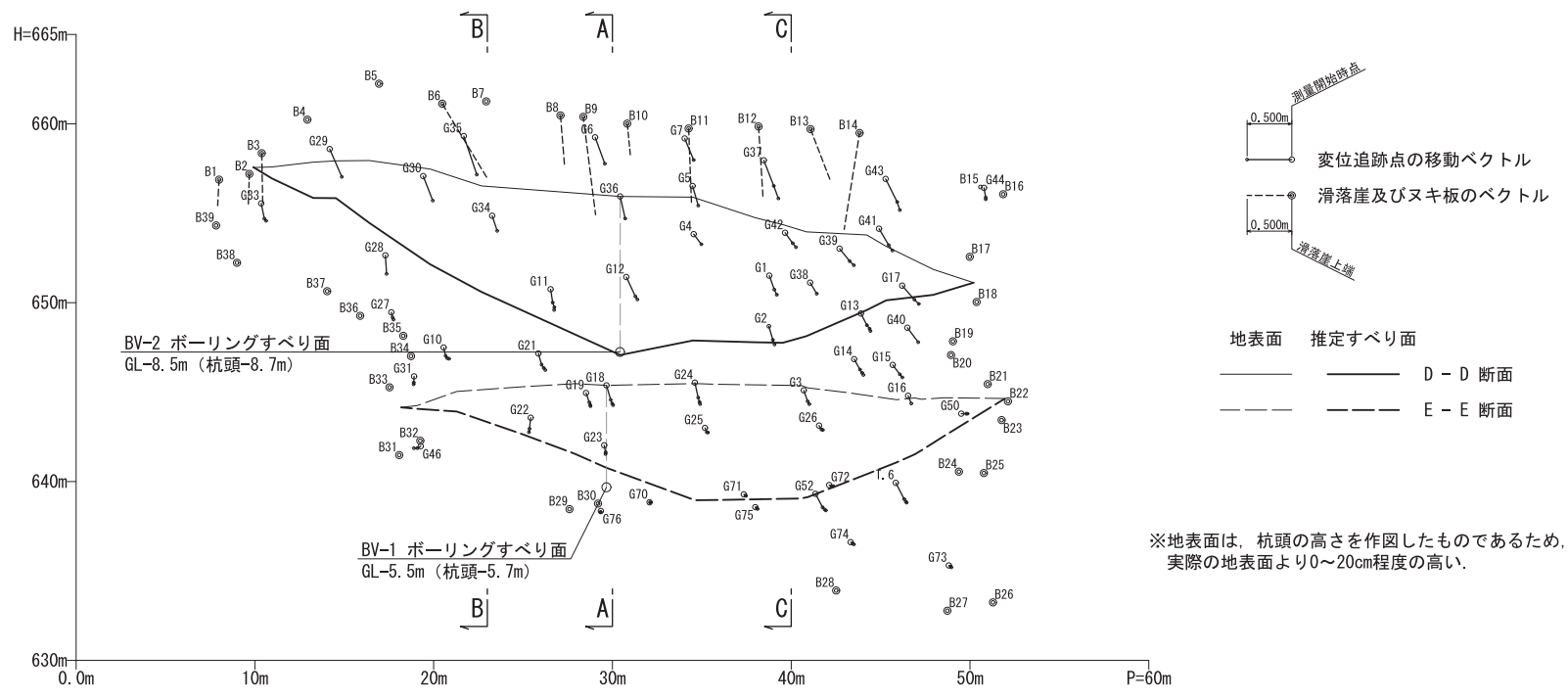

(c) 横断方向（直角方向）断面図

図一15＼cjkstart相道寺地すべり解析条件(1)：ボーリングデータを用いない推定結果断面図

Fig. 15 Cross section diagram of sliding shape of Aidoji landslide under the analytical condition 1 (not using boring data) 


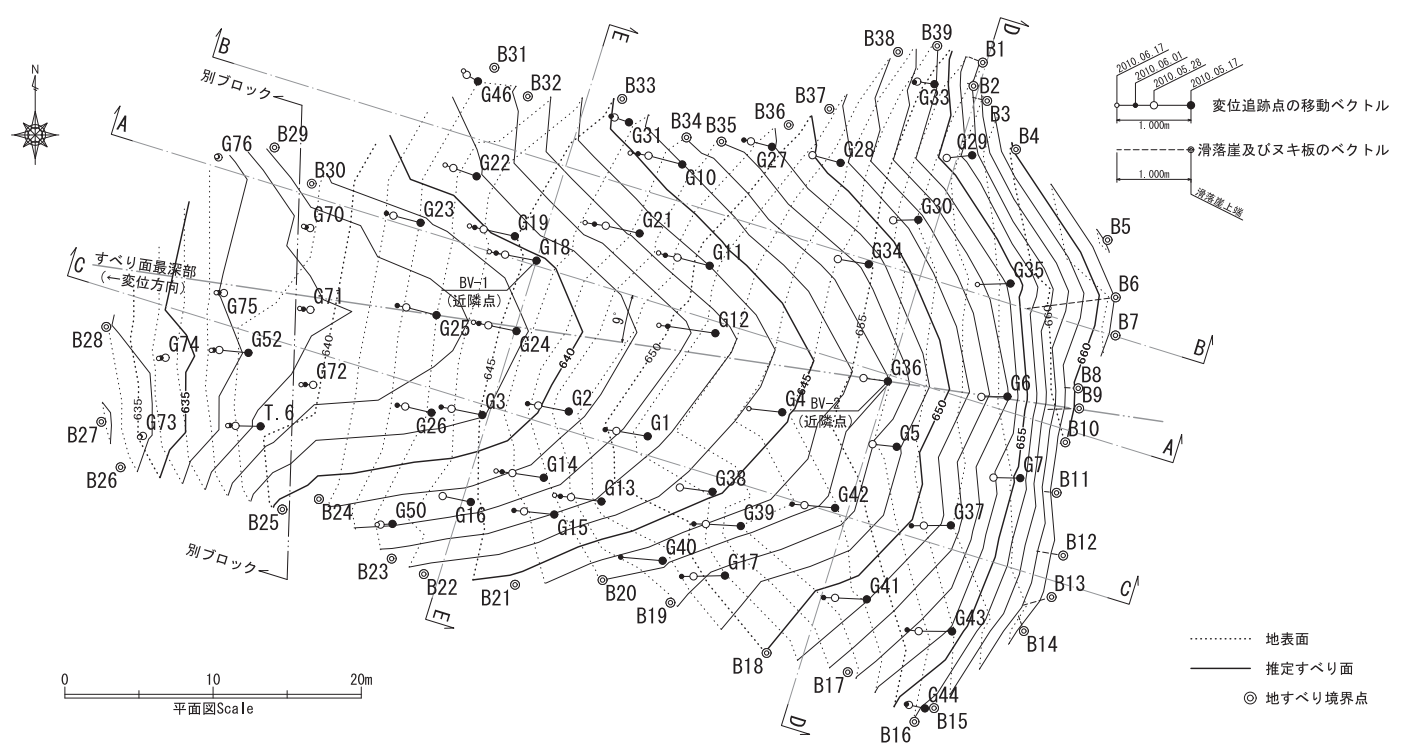

図ー16 相道寺地すべり解析条件(3)：ボーリングデータBV-1を用いた推定結果平面図（等高線表示）

Fig. 16 Plane figure of sliding shape of Aidoji landslide under the analytical condition 3 (using the bore hole BV-1data)

既知深度として用いる

解析条件(3)：BV-1 のボーリング調査結果をすべり面の 既知深度として用いる

解析条件(4)：BV-1，BV-2 の調査結果をすべり面の既 知深度として用いる

解析条件(1)の推定結果を図-14 (平面図), 図-15 (断 面図）に示す。各解析条件の共通した結果として，道路 から下側（G70，G71，G72より西側）は，すべり面の 勾配が上方より若干急になることから，道路付近を脚部 末端とする地すべり本体によって押し出された別のブ ロックであると判断する。

図-15(a)のA-A断面は, 図-12 と同位置の断面図で ある。図-12の「地質調查による推定すべり面」を図一 15 (a)に示す。これと本手法による A-A断面の本体ブ ロックの推定結果を比較すると，頭部及び脚部の形状は 類似した結果となった。G36下（BV-2）では0.1mしか 差がない。しかし中間部では差が増し，最大 $1.0 \mathrm{~m}, \mathrm{G}$ 18下（BV-1）で $0.9 \mathrm{~m}$ 程度の較差がある。

解析条件(2)は，解析結果(1)に類似した結果となったた め図示を省略する。これは解析条件(1)の推定結果が, BV -2のすべり面とほぼ一致するためである。

解析条件(3)の推定結果を図-16, 図-17に示す。推定 すべり面は「地質調査による推定すべり面」とほぼ一致 した結果となり,較差は最大でも $0.2 \mathrm{~m}$ と大変小さくなっ た。解析条件(4)は解析条件(3)と類似した結果となったた め図示を省略する。

相道寺地すべりでは，ボーリングデー夕を使用しなく ても（解析条件(1)）かなり精度の高いすべり面の推定が できた。またBV-1 のボーリング調査結果を用いた場合 （解析条件(3) では，1本のボーリングデー夕を解析に用 いることで，推定精度が向上することを実証できた。し かし解析条件(2)のように，ボーリングデー夕を使用して
も推定結果が使用しない場合とほとんど変わらないこと もある。

推定結果平面図（図-16）によると，本解析法による 推定すべり面では，G36とG25を結んだ線付近にすべり 面の最深部があり，ボーリングを行った $\mathrm{A}-\mathrm{A}$ 測線より 反時計回りに $9^{\circ}$ 程度の角度差がある。各変位追跡点は 概ねこの方向に変位していることがわかる。

相道寺地すべりでは，地すべり発生から10日後に情報 を入手し，現場に入ったのは応急対策工事が終わった発 生から 1 个月弱であった。地すべり発生後比較的早期の デー夕を得ることができ，その結果精度の良い推定結果 が得られたものと考えられる。

情報入手前の 3 日間で，伸縮計で $5 \sim 7 \mathrm{~cm}$ 程度の変 位量を記録していた。発生直後に情報を得ていれば，応 急対策工事の前に推定すべり面を提示することができた 可能性が高い。

\section{5. まとめ}

地すべり地における地表変位測量デー夕を解析して, すべり面の三次元形状を推定する手法として, 現地の状 況に応じた種々の任意形状のすべり面を推定できる「多 面体法」を新たに開発し，これを実際に発生した地すべ りに適用してすべり面推定の精度を検証した。本研究を 通じて得られた結論を以下に要約する。

(1)すべり面の形状を地中TINモデルで近似する「多面 体法」は，これまでに提案した三次元解析の「複合多項 式曲面法」 ${ }^{5), 11 \sim 13}$ に比べると解析上の理論も手順も簡明 であり，現場への早急な対応の上で実用的な手法である。 (2)すべり面推定の三次元解析 ${ }^{5,9)}$ (13) は，投影断面図上で すべり面形状を推定する二次元解析 ${ }^{1) ~-8)}$ に比べて効率が 良い。すなわちすべり面形状に関する地中等高線図の作 成と共に，任意方向の断面上でのすべり面の表示は容易 


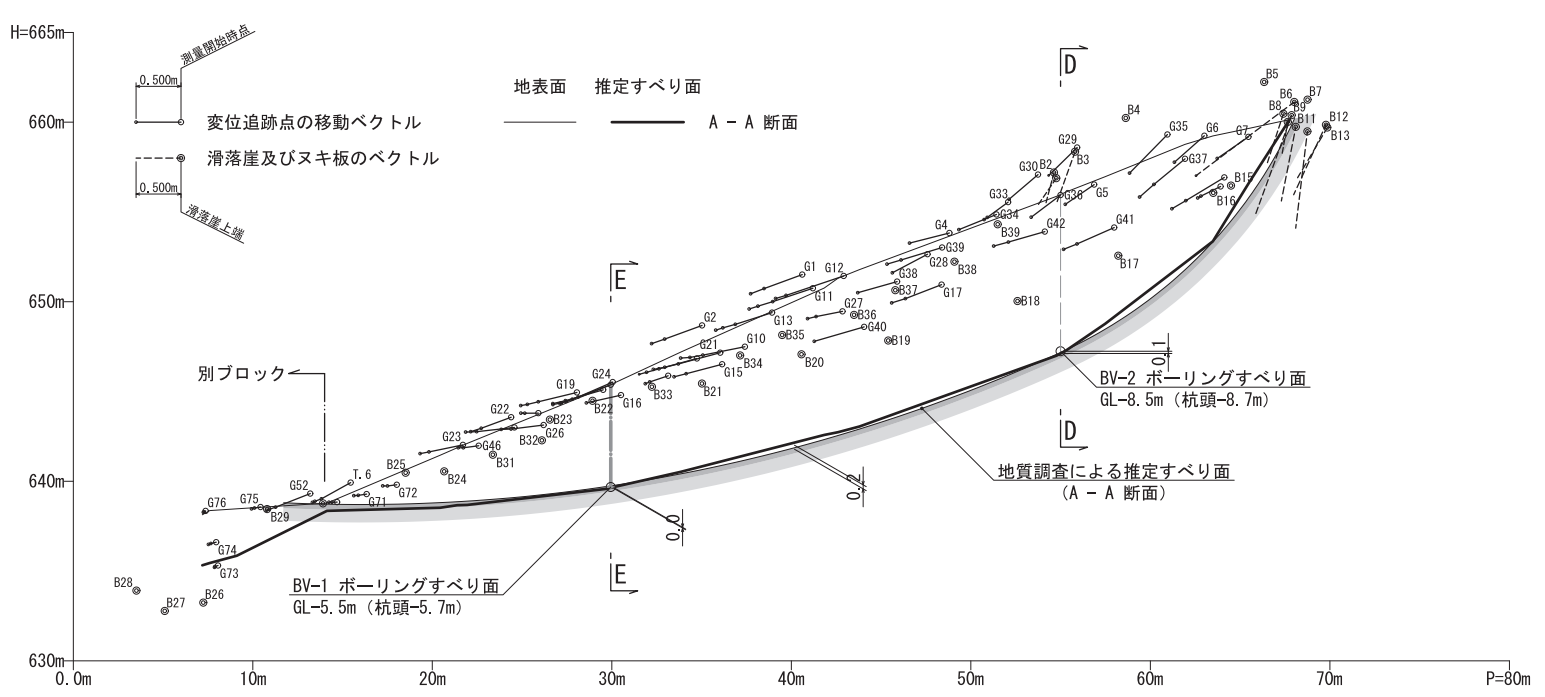

(a) 縦断方向 (斜面傾斜方向) A - A 断面

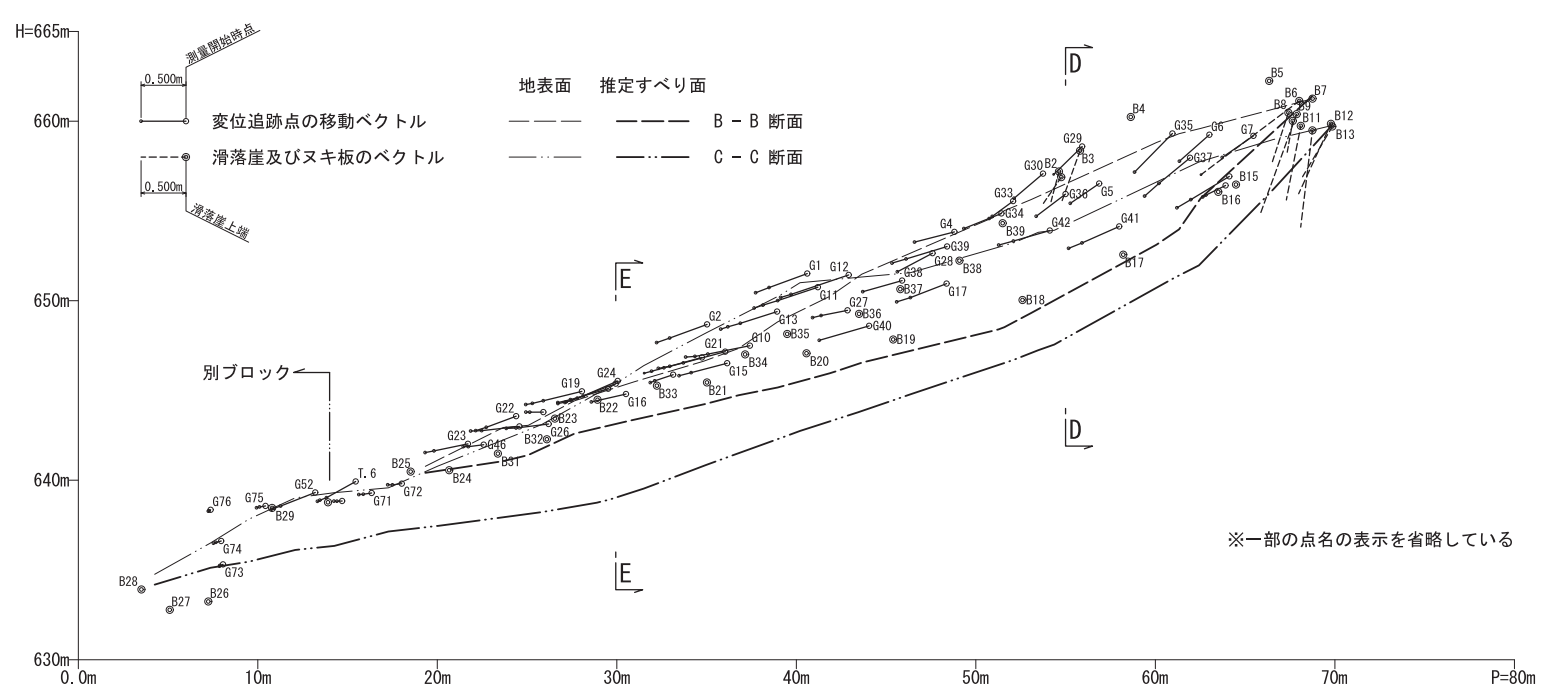

(b) 縦断方向（斜面傾斜方向） B - B, C - C 断面

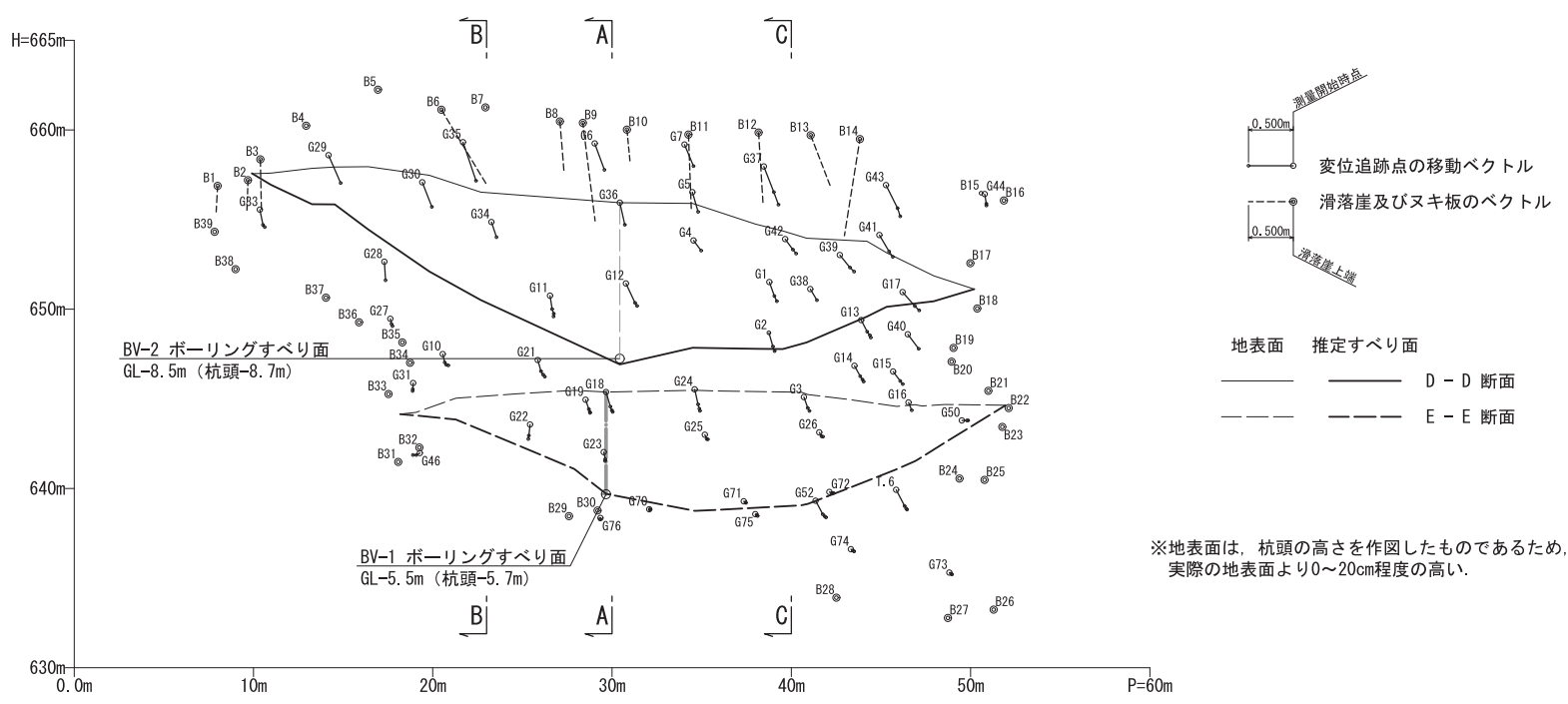

(c) 横断方向（直角方向）断面図

図ー17 相道寺地すべり解析条件(3)：ボーリングデータBV-1を用いた推定結果断面図

Fig. 17 Cross section diagram of sliding shape of Aidoji landslide under the analytical condition 3 (using the bore hole BV -1 data) 
であり，特に多面体法が簡便である。

(3) 現地の地形調査による「滑落崖べクトル」の概念を 新たに導入した。これを破壊現象の激しい滑落崖付近の 変位ベクトルとして解析に加えると, 推定精度の向上に 寄与する。なお，滑落崖べクトルはこれまでに公表して きたすべての解析手法にも導入できるものである。

(4) 地表変位べクトルを用いたすべり面推定解析におい て，筆者らはこれまでに，解析上の仮定や境界条件の信 頼度を考慮して，それぞれの変位追跡点や境界点のデー 夕に重みを付けた最小二乗法によって推定精度の向上を 試みている ${ }^{4), 9), 11}$ 。多面体法においても重みの導入が可 能である。

(5)現地ボーリングで確認されたすべり面の三次元位置 を 1 点でも境界条件に加えると，本法によるすべり面形 状は，これまでの慣用的な地形・地質調査による推定す ベり面にかなり近くなる。特に変位追跡点密度の疎らな 領域でのボーリングデータは効果的である。

(6)多面体法は，これまでのすべり面推定手法に比べ, より多くの変位追跡点を一様な密度で設置することが, 解析精度を向上させる上で肝要である。測量手法は現地 条件に応じて選択する。

（7）これまでに提案してきた，地表変位追跡測量による すべり面推定解析理論は「すべり面上を移動する地山の 変形量は地山の移動量に比べて無視できるほど小さい」 という大前提のもとに構築されている。本稿ではこの前 提が成り立つ「早期対応型」と前提が危ぶまれる「遅延 対応型」の事例を比較して，「早期対応型」の有効性を 立証することができた。

今後の課題として, 変位追跡点や境界点の信頼度を厳 密に評価した，重み付き最小二乗法による多面体法を検 討していきたい。これによって推定精度はかなり向上す るものと考えられる。

また，筆者らはこれまでに各種の現場の条件に応じて トータルステーション測量と空中写真測量 ${ }^{3), 7)}$,15) で対応

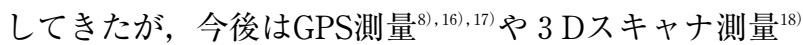
による変位追跡法も検討していくことを考えている。

\section{6 . 謝辞}

本研究の実施に際し, 長野県長野地方事務所林務課 (新 安地すべり）及び長野県犀川砂防事務所（相道寺地すべ り）には貴重な資料やデータを提供していただきました。 また(株) 北陽建設には相道寺地すべりにおいて対策工事 施工中にもかかわらず，測量調査に協力していただきま した。ここに記して厚く感謝いたします。

本研究の一部は，(財) 日本建設情報総合センターより 研究助成を得た。記して謝意を表します。

\section{参考文献}

1 ）吉澤孝和・細川容宏（1987）：地すべり地における地表変位測 量データを用いた円弧すべりの解析, 地すべり, Vol. 23, No. 4, pp. $13-23$.

2 ）吉澤孝和（1988）：多角形法による地下すべり面の推定（地す ベり地における四次元測量の利用法), 地すべり, Vol. 25, No. 2 , pp. $9-17$.

3 ）吉澤孝和・西澤茂高・三澤敏雄・根岸六郎（1991）：地すべり の挙動解析における写真測量の応用，写真測量とリモートセ ンシング, Vol.30, No.5, pp. 8-20.

4 ）宮澤圭・吉澤孝和（1998）：地下すべり面推定に用いる地表変 位測量デー夕の重みに関する考察，応用測量論文集，Vol. 9, pp. $47-54$.

5 ）吉澤孝和 (2005)：図解測量学要論, (社) 日本測量協会, pp. 392 -409 .

6 ) M. Carter and S. P. Bentley (1985) : The Geometry of Slip Surface beneath Landslides: Predictions from Surface Measurements, CAN. GEOTECH. J. Vol. 22, pp. 234-238.

7 ) 羽田野誠一 - 関根清 - 鈴木隆介・高橋健一 ・石野浩一・柳林 実・見里文之（1974）：中央道岩殿山地すべりについて，日本 地理学会予稿集, Vol. 6, pp134 135.

8 ）藤沢和範 - 小嶋伸一（2009）：高精度地表面変位計測による迅 速な切土地すべりの規模推定手法に関する調查, 国土技術政 策総合研究所資料, Vol.516, pp. 157-164.

9 ）吉澤孝和・宮澤圭（1992）：地下すべり面推定における三次元 変位軌跡法の改良, 地すべり, Vol. 28, No. 4, pp. 6-14.

10）吉澤孝和（1995）：地すべり解析のための三次元地表変位測量 と考察, 自然災害科学, Vol. 14, No. 1, pp.13-29.

11）宮澤圭・吉澤孝和（1998）：地すべり地の空中写真測量デー夕 の重みを考慮した三次元地下すべり面形状の推定，写真測量 とリモートセンシング, Vol.37, No.6, pp.14-27.

12）宮澤圭・吉澤孝和（2000）：地すべり地の地表変位䀧量データ を利用した三次元すべり面形状の推定，土木学会論文集， No. $645 / \mathrm{III}-50$, pp. 51-62.

13）宮澤圭・吉澤孝和・小野塚良三・久松文男（2000）：時間差空 中写真測量による地すべり解析システム一八幡平澄川地すべ り地の変位計測データを利用した地下すべり面の推定一, 写 真測量とリモートセンシング, Vol. 39, No.1，pp. 39-47.

14）長野県長野地方事務所（2009）：平成20年度地すべり防止事業 第 8 工事 (調査等業務委託) 報告書 (長野市字新安地内), pp. 1 -83 .

15）吉澤孝和・酒井輝雄 - 宮野尾文男 - 根岸六郎 - 関貴幸 （1994）：空中写真による地下すべり面形状解析システム，写 真測量とリモートセンシング, Vol.33，No.3,pp.17-32.

16）近藤仁志・M. E. Cannon・清水則一・中川浩二（1996）：GPS による地表変位モニタリングシステムの開発, 土木学会論文 集, No. 546/VI-32, pp. 157-168.

17）岡本修・安田明生・浪江宏宗（1998）：RTK-GPSの地すべり 計測への適用に関する実験的研究，応用測量論文集，Vol. 9, pp. $55-62$.

18）光岡操・高木方隆（2003）：レーザースキャナを用いた地すべ り変位観測のための三次元モデリング, 日本写真測量学会平 成15年度秋季学術講演会発表論文集, pp. 51-54. （原稿受付2011年 1 月18日，原稿受理2011年11月18日） 